LL난, BANCO CENTRAL DO BRASIL

Housing Collateral Reform and Economic Reallocation

Dimas Mateus Fazio and Thiago Christiano Silva

May 2020

Working Papers
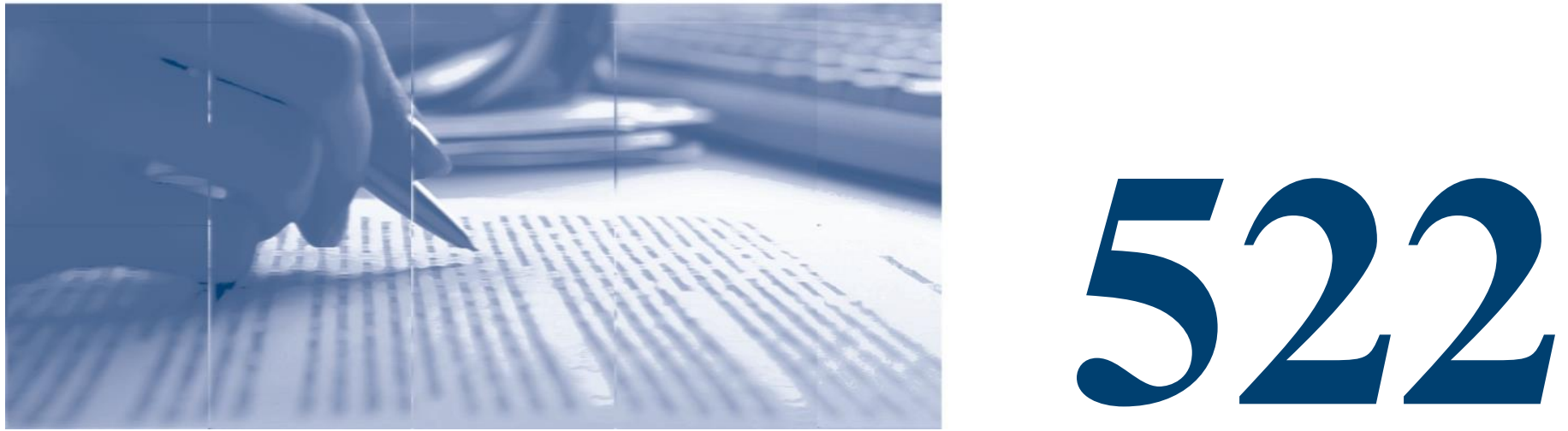


\section{Working Paper Series}

Edited by the Research Department (Depep) - E-mail: workingpaper@bcb.gov.br

Editor: Francisco Marcos Rodrigues Figueiredo

Co-editor: José Valentim Machado Vicente

Head of the Research Department: André Minella

Deputy Governor for Economic Policy: Fabio Kanczuk

The Banco Central do Brasil Working Papers are evaluated in double blind referee process.

Although the Working Papers often represent preliminary work, citation of source is required when used or reproduced.

The views expressed in this Working Paper are those of the authors and do not necessarily reflect those of the Banco Central do Brasil.

As opiniões expressas neste trabalho são exclusivamente do(s) autor(es) e não refletem, necessariamente, a visão do Banco Central do Brasil.

\section{Citizen Service Division}

Banco Central do Brasil

Deati/Diate

SBS - Quadra 3 - Bloco B - Edifício-Sede - $2^{\circ}$ subsolo

70074-900 Brasília - DF - Brazil

Toll Free: 08009792345

Fax: +55 (61) 3414-2553

Internet: http//www.bcb.gov.br/?CONT ACT US 


\section{Non-Technical Summary}

Governments around the world have been implementing policies to improve creditor protection and expand the options of collateralizable assets with the primary objective of increasing access to the credit market by individuals and firms. There is extensive empirical evidence that these reforms have led to a more developed credit market and improved access to credit, as initially intended. However, there is still much we do not know about the indirect and possibly unintended consequences of these laws. If banks' decision to lend to a particular borrower depends on the credit conditions of other borrowers, then changes in creditor rights to some might also affect the allocation of credit to others. This paper examines how banks reallocate credit across borrowers as a result of a reform that improved the repossession of real estate collateral and its consequences to local economic performance.

This paper exploits a housing collateral reform in Brazil in 2004 that improved the speed of repossession of real estate assets given as a guarantee of any debt obligation. In case of default of a home-backed loan, creditors could quickly repossess the collateral under this new contract, sharply reducing their expected loss given default. We find that municipalities with a higher homeownership rate experienced a sharp increase in bank credit supply after the implementation of the law. This result is consistent with homeowners now being able to access the credit market since they can get better loan terms by pledging their homes as collateral. This improved credit supply also led to higher employment, wages, and the creation of firms, suggesting a significant boost in entrepreneurial activity as a result of unlocking the housing collateral.

At the same time, however, banks restricted the credit supply to non-homeowners. We show that banks that are ex-ante more exposed to the housing collateral law decreased their total lending and increased the overall interest rate to borrowers in low homeownership municipalities. Since the housing collateral law benefited areas with higher homeownership, banks have reallocated their credit towards these areas and away from low homeownership municipalities. This substitution effect is stronger when banks cannot raise funding easily, i.e., when they are less liquid and less capitalized. We also find significant real economic consequences because of this credit restriction. Opposite to what we have found for the intended outcomes of this housing collateral law, we find that employment, wages, and entrepreneurship sharply decreased in low homeownership municipalities after the reform.

Finally, we ask whether the credit reallocation triggers a redistribution of other economic factors, such as labor. We do find evidence that workers switched jobs from low to high homeownership municipalities after the housing collateral law of 2004. The job migration is stronger for municipalities that are more affected by the drop in credit supply due to the reallocation.

Overall, our results show that stronger creditor protection might benefit some borrowers at the expense of others through a bank credit portfolio channel. Regulators and policymakers should be aware of the possible credit redistribution as a consequence of these policies. 


\section{Sumário Não Técnico}

Governos ao redor do mundo têm implementado políticas que fortalecem a proteção ao credor e expandem as opções de ativos que podem ser dados com garantias de dívidas tais como empréstimos bancários. O objetivo dessas políticas é aumentar o acesso ao crédito para indivíduos e firmas. Há fortes evidências de que essas reformas de fato incentivaram o desenvolvimento do sistema financeiro, com efeitos positivos na economia. No entanto, ainda há muito que não sabemos sobre consequências indiretas e provavelmente indesejadas dessas leis. Por exemplo, ao decidir emprestar para um determinado indivíduo ou firma, bancos podem também levar em consideração os benefícios e custos de se emprestar para outros potenciais tomadores de empréstimos. Dessa forma, uma melhoria no retorno esperado do empréstimos para determinados indivíduos pode ser propagada para outros por meio de mudanças na alocação de crédito bancário.

Este artigo aborda a questão de como bancos realocam crédito na economia como consequência de uma lei que incentivou o uso de empréstimo com garantia imobiliária (home-backed loans) no Brasil em 2004. Essa lei permitiu tomadores transferir o título de seus ativos imobiliários para os credores como garantia de qualquer dívida (alienação fiduciária). Em caso de inadimplência, os credores poderiam facilmente consolidar a posse do ativo e liquidá-lo em leilão, o que diminuiu significantemente o prejuízo esperado desses credores em caso de inadimplência. Por um lado, este artigo mostra que municípios com maior proporção de proprietários de imóveis residenciais tiveram uma maior oferta de crédito bancário após a lei. Este melhor acesso a crédito também teve efeitos na economia real desses municípios, pois gerou empregos, aumentou o salário médio e o número de empresas criadas nessas localidades.

Por outro lado, bancos restringiram a oferta de crédito para não proprietários de imóveis residenciais, ou seja, aqueles que não foram diretamente afetados pela lei. A intuição deste resultado é que, ao se aumentar o retorno de empréstimos de com garantia imobiliária (home-backed), bancos realocaram crédito para proprietários de imóveis e reduzem crédito a não proprietários. Esta substituição é mais evidente quando é difícil quando bancos estão enfrentando restrições financeiras tais como de capital e de liquidez. Encontram-se também efeitos reais negativos desta realocação. Em áreas com baixa proporção de proprietários, emprego, salário e empreendedorismo diminuem significantemente após a lei.

Por fim, este artigo analisa se a realocação de crédito também gerou uma realocação de fatores de produção, como trabalho. De fato, há evidência que trabalhadores trocam de emprego de municípios com baixa para municípios com alta proporção de proprietários. Esta migração de trabalhadores é mais intensa em municípios que foram mais afetados pela queda de oferta de crédito, o que caracterizaria a realocação de crédito como uma das causas desta migração.

De modo geral, nossos resultados mostram que melhorar a proteção ao credor pode beneficiar alguns tomadores de empréstimo em detrimento de outros. Formuladores de políticas precisam estar atentos à possível redistribuição de crédito como consequência dessas políticas. 


\title{
Housing Collateral Reform and Economic Reallocation*
}

\author{
Dimas Mateus Fazio** \\ Thiago Christiano Silva ${ }^{* * *}$
}

\begin{abstract}
This paper examines how banks reallocate credit after the introduction of a more enforceable housing collateral contract in Brazil. This new contract greatly improved the repossession of real estate assets used as collateral for personal and business loans. We find opposing effects of this policy. Because of the stronger enforcement, credit supply increased in municipalities with higher homeownership, leading to the creation of new firms, higher employment, and economic performance. However, banks restricted credit to borrowers in low homeownership municipalities. These areas experienced a decline in entrepreneurship, local labor demand, and economic activity. The credit reallocation was greatest for credit-constrained banks, consistent with higher external financing costs. Finally, the differential effects in credit supply induced a redistribution of labor in the economy: workers migrated from low to high homeownership municipalities after the reform.
\end{abstract}

Keywords: collateral reforms, home-backed loans, bank credit spillovers, entrepreneurship, regulatory constraints

JEL Classification: G21, K22, O16

The Working Papers should not be reported as representing the views of the Banco Central do Brasil. The views expressed in the papers are those of the authors and do not necessarily reflect those of the Banco Central do Brasil.

\footnotetext{
${ }^{*}$ We are extremely grateful to Julian Franks, David Schoenherr, Janis Skrastins and Vikrant Vig for valuable suggestions and discussions. We would also like to thank Sérgio Afonso Lago Alves, Simcha Barchai, Taylor Begley, Bo Bian, Daniel Cajueiro, João Cocco, Rebel Cole (discussant), Marc Gabarro, Francisco Gomes, Apoorv Gupta (discussant), Marco Grotteria, André Minella, Andrea Presbitero (discussant), Ashish Sahay, Arkodipta Sarkar, Sergio Rubens Stancato de Souza, Mikhail Tirskikh, Bernardus Van Doornik, Luofu Ye, participants of internal seminars at London Business School, seminars at the National University of Singapore, Hong Kong University of Science and Technology, Chinese University of Hong Kong, BI Business School, Purdue University, the 5th HEC Paris Finance PhD workshop, the XIII Annual Conference on Financial Stability and Banking of the Central Bank of Brazil, the 1st LBS PhD Alumni Workshop, the Trans-Atlantic Doctoral Conference (TADC-LBS), and the 32nd Australasian Finance and Banking Conference (AFBC-UNSW). We would also like to thank an anonymous referee at the Central Bank of Brazil. Dimas Fazio gratefully acknowledges financial support from the Deloitte Institute of Innovation and Entrepreneurship at London Business School. Thiago Silva (Grant no. 308171/2019-5, 408546/2018-2) gratefully acknowledges financial support from the CNPq foundation.

** London Business School, 26 Sussex Pl, Marylebone, London NW1 4SA, Email: dfazio@ london.edu

*** Central Bank of Brazil, Setor Bancário Sul Q. 3 BL B - Asa Sul, Brasília - DF, Brazil, 70074-900, Email: thiago.silva@bcb.gov.br
} 


\section{Introduction}

Effective creditor protection plays an essential role in promoting economic development (La Porta et al., 1997, 1998; Levine, 1998, 1999). According to contract theory, when creditors can recover a higher fraction of their loans in the event of a default, they are more likely to offer better loan terms ex-ante in the form of larger funding at a lower interest rate. ${ }^{1}$ This increased credit availability expands access to finance to previously constrained borrowers and ultimately fosters economic growth (King and Levine, 1993). Because of these positive consequences, governments around the world have been implementing a series of reforms to improve contract enforcement and repossession of collateral to incentivize lending. ${ }^{2}$

While there is extensive empirical evidence on the effects of stronger creditor protection - including contract enforceability — we understand little about their reallocative effects. ${ }^{3}$ In particular, a bank's decision to lend to one borrower may also affect its ability to lend to another. ${ }^{4}$ Improving creditor rights might benefit some borrowers at the expense of others, because credit-constrained banks may optimally rebalance their loan portfolio towards loans that benefit more from an improvement in credit protection.

This paper studies how banks reallocate credit as a result of a Brazilian collateral reform in 2004 and its consequences for real economic performance. The reform improved the repossession of real estate collateral attached to home-backed loans, such as personal and business loans. ${ }^{5}$ We find that municipalities with a higher proportion of homeowners experience an increase in bank credit supply, consistent with their higher real estate collateral pledgeability after the reform. This, in turn, leads to the creation of new firms, greater labor demand and economic activity in these municipalities. However, banks finance this increase in lending by restricting credit to borrowers in municipalities with low homeownership, especially if banks are financially constrained. The credit restriction affects firms' financing costs, leading municipalities with lower homeownership experience fewer businesses creations and reduced labor demand and economic activity. Finally, not only credit but also labor is reallocated: there is an increase in the number of workers changing jobs from low to high homeownership municipalities after the reform. Overall, we show that bank credit spillovers might have unintended side effects on initially unaffected borrowers.

To understand the direct and indirect effects of stronger creditor protection, we exploit a 2004 reform in Brazil that introduced a new collateral contract for home-backed loans, i.e., loans for personal and

\footnotetext{
${ }^{1}$ Jappelli et al. (2005) highlight the enforceability of contracts as one important aspect for fostering credit supply.

${ }^{2}$ Recent studies have studied the effects of these reforms on India (Visaria, 2009; Vig, 2013), Romania (Campello and Larrain, 2016), Slovakia (Calomiris et al., 2017), Sweden (Cerqueiro et al., 2016), and Brazil (Van Doornik and Capelletto, 2015; Ponticelli and Alencar, 2016; Fonseca and Van Doornik, 2019).

${ }^{3}$ Notable exceptions are the papers by Vig (2013) and Donaldson et al. (forthcoming). Both papers find that under certain conditions, access to finance decreases after the pledgeability of collateral increases.

${ }^{4}$ See Klein (1971) and Hannan (1991) for a model that would be consistent with this finding. In a model where banks lend through different loan categories/markets, and they have market power on both credit and deposits, bank's optimal decision to lend to one market depends on the cost of lending to other markets.

${ }^{5} \mathrm{~A}$ subset of this collateral is home-equity loans, where homeowners pledge their house as collateral and get a lumpsum payment that needs to be repaid over a set period of time. In this paper, we also consider housing collateral given as guarantee against other assets, such as machinery and equipment, as well.
} 
business reasons. This contract - the fiduciary lien of real estate assets — allowed banks to retain the title of the house until the debt is repaid. Because the banks retained the title, repossession could be gained without resort to the courts. ${ }^{6}$ This change greatly enhanced the speed of repossession in case of default over the previous judicial contract. ${ }^{7}$ While creditors of home-backed loans would have to wait three years on average to get court approval to liquidate the collateral in case of default, the new 2004 contract allowed the real estate collateral to be seized and auctioned in only one to two months after default.

We estimate the direct effects of the housing collateral law by comparing bank lending in municipalities with high and low homeownership around the time of the reform in a differences-in-differences setting. ${ }^{8}$ We find that municipalities with a one standard deviation higher homeownership experience an increase of nine percent in total credit in 2007 compared with before the housing collateral law. Most of this increase in lending is explained by home-backed loans: the proportion of home-backed loans to total credit increases by around one percentage point in areas with a one standard deviation higher homeownership. Interest rates of these home-backed loans also decrease by 27 basis points (or $1.3 \%$ in terms of its unconditional average) in these municipalities. Since homeownership might be correlated with other municipality-specific characteristics, we compare municipalities with different homeownership rates but located nearby and with similar average income levels. We confirm that our findings are not driven by possible intrinsic differences between high and low homeownership municipalities. These results suggest an expansion of credit supply in regions with higher homeownership, consistent with the initial governments' intention in enacting the housing collateral law.

While banks increase credit supply in high homeownership areas after 2004, we also assess if and how credit supply changes to borrowers in municipalities with low homeownership. To identify changes in credit supply to borrowers in these areas, we compare lending by banks with different sensitivity to the housing collateral law. We define sensitivity as the fraction of banks' credit portfolio in municipalities with homeownership rates above the national median.

These results suggest that banks reallocate credit from municipalities with low to high homeownership after the housing collateral law. Nevertheless, if banks could easily finance the increase in credit to homeowners by increasing leverage or selling other assets, we would not expect lending to decrease to some borrowers. Consistent with this idea, we find evidence that financial frictions that prevent banks from raising external funding also explain why this reallocation takes place in the first place. Less liquid and less capitalized banks restrict credit the most to firms in low homeownership areas. When it is costlier for banks to raise external funding, the increase in lending in high homeownership municipalities should be financed by restricting credit elsewhere.

\footnotetext{
${ }^{6}$ Bankruptcy procedures in other countries also permit lenders to repossess collateral without resort to the courts. For example, English receivership at administration procedures.

${ }^{7}$ The fiduciary lien of real-estate assets was actually created in 1997. Initially, however, this contract was limited in scope: it could only be used to purchase a new house. It could not be used by an existing homeowner to further exploit the collateral by pledging it for other purposes, such as financing a business or consumer purchases. Only in 2004, were homeowners allowed to pledge their house as collateral against any debt under the new contract. We further discuss this reform in Section 2.

${ }^{8}$ Municipalities are defined as the smallest autonomous territorial division in Brazil. An average municipality in Brazil has an area of $1600 \mathrm{~km}^{2}(40 \mathrm{~km} \times 40 \mathrm{~km})$.
} 
Our reallocation results above assume that less sensitive banks do not compensate for the credit restriction by taking up the slack of sensitive banks. If this assumption does not hold, then our reallocation estimates may be biased upward in absolute terms. To address this concern, we compare total borrowing by similar firms in the same municipality and industry but connected ex-ante to banks with different sensitivity to the reform. To the extent that firms can fully compensate for the lower credit supply of sensitive banks, we should not observe differences in bank debt for these two similar firms. We find evidence to the contrary. Firms with a one standard deviation higher bank sensitivity experience a drop of $5.2 \%$ in credit and an increase of about 1 percentage point in the interest rate charged compared to other similar sized firms in the same local industry. Consistent with the inability of firms to substitute bank credit, we also find that smaller and younger firms are affected the most by the credit restriction.

Next, we examine the real economic consequences of this bank credit reallocation. We first study its consequences for entrepreneurship and new business creation. Housing wealth and the ability to effectively use it as collateral are relevant for entrepreneurial activity. ${ }^{9}$ Consistent with this hypothesis, both the number of new business created and the number of entrepreneurs increase in high homeownership municipalities after the 2004 housing collateral law. However, entrepreneurial activity in low homeownership municipalities declines as both the number of new firms and entrepreneurs drop after the reform. There is also evidence that these results are explained by the differential availability of credit in these municipalities.

We also find significant effects of the credit reallocation on firms' and local economic performance. Firms in high homeownership municipalities increase sales and their demand for labor — since both the number of employees and average wage increase - after 2004. The other side of the coin is that the performance of firms located elsewhere and connected to banks with higher sensitivity to the reform deteriorates after the reform. Firms connected to sensitive banks experience a decrease in employment, average wage, and sales when compared to other firms in the same local industry.

Besides the heterogeneous effects on firms and economic activity, the housing collateral law also seems to explain a reallocation of labor across municipalities. With data on the universe of formal labor contracts in Brazil, we can follow the job history of every employee. We then compare changes in workers' migration flow across municipalities with different homeownership rates. Empirical results show migration from low to high homeownership municipalities after the housing collateral law. This effect is also stronger when workers start working in firms whose owners have a positive outstanding homebacked loans balance. These results are consistent with better access to credit in high homeownership municipalities, leading to a shift of jobs across the country. Finally, the migration is stronger when, at the origin, there is a higher presence of sensitive banks, i.e., where credit was restricted the most. Overall, the effects of stronger creditor rights on the allocation of resources are not limited to credit but also impact real economic factors.

Throughout the paper, we have assumed that changes in bank credit in high versus low homeownership municipalities are a result of the housing collateral law only. We perform a series of robustness tests to provide evidence that this assumption holds in the data. First, since the fiduciary lien allowed for the

\footnotetext{
${ }^{9}$ See, for instance, Evans and Leighton (1989), and Evans and Jovanovic (1989).
} 
extrajudicial execution of the collateral in case of default, one should expect the direct effect on credit to be stronger where courts are weak. We take information on court congestion - defined as the number of pending cases by the number of judges for each Brazilian municipality - and show that bank lending increases in areas with higher homeownership and weaker courts after the implementation of the law. Second, since the reform affected home-backed loans only, it should not have affected real estate lending. That is precisely what we find: real estate lending does not change in municipalities with different homeownership rates around the reform. Third, we also make sure that contemporaneous reforms in Brazil do not explain our findings. For instance, in 2004, there was also an improvement in the repossession of automobiles given as a guarantee to finance their acquisition (see Assunção et al., 2014). Also in 2004, the federal government introduced a cash transfer program that was aimed at low-income individuals, the Bolsa Família Program. ${ }^{10}$ We show that car loans and the disbursements of the Bolsa Família do not increase in areas with higher homeownership.

We perform robustness tests of our credit reallocation results, as well. We show that our choice of looking at firms that borrowed from multiple banks does not drive our results. If anything, the effects are stronger when we include single-lender firms in the analysis, suggesting that our benchmark results are conservative. To further alleviate concerns of sample representativeness, we also consider a specification where we look at lending to individuals located in low homeownership municipalities. We find similar results to our benchmark specifications. Second, we also present additional tests to support the credit reallocation channel. We take balance sheet information on the intrabank borrowing and lending of each branch and document that branches in higher homeownership municipalities increase their net intrabank borrowing after the law. Other branches appear to be funneling capital towards branches in higher homeownership municipalities, which gives further support to our results.

This paper contributes to the extensive literature on creditor rights. Seminal contributions by La Porta et al. (1997, 1998), and Levine (1998, 1999) emphasize that the stronger credit contract enforcement fosters the financial and economic development. Several recent contributions support this traditional view (Campello and Larrain, 2016; Calomiris et al., 2017; Cerqueiro et al., 2016; Ponticelli and Alencar, 2016). Among the few exceptions, Vig (2013) shows that stronger creditor enforcement may lead to lower credit demand by borrowers due to the fear of inefficient liquidation of the collateral. In a paper close to ours, Lilienfeld-Toal et al. (2012) show heterogeneous consequences of stronger creditor rights for different borrowers. ${ }^{11}$ They argue that creditor rights increase the overall demand for credit, which increases interest rates and crowds out poorer firms. Our paper looks at how banks shift supply across borrowers and the role of regulatory and financial constraints in exacerbating this reallocation. We also document relevant heterogeneous real effects and labor reallocation due to the reform.

This paper is also related to the literature on home-equity and entrepreneurship. There is extensive evidence that one of the deterrents of new business creation by entrepreneurs is their credit and financial constraints (Evans and Leighton, 1989; Evans and Jovanovic, 1989; Black and Strahan, 2002; Cetorelli and Strahan, 2006; Kerr and Nanda, 2009). Since most of the households' wealth is locked on home-

\footnotetext{
${ }^{10}$ The introduction of these programs could potentially explain our results, since high homeownership municipalities usually have lower average income as will be discussed in Section 4.

${ }^{11}$ Other works with similar findings are Gropp et al. (1997), Kulkarni (2018) and Bian (2019).
} 
ownership, ${ }^{12}$ the ability to pledge real estate collateral against personal and business loans facilitate entry into entrepreneurship (see evidence in Adelino et al., 2015; Corradin and Popov, 2015; Schmalz et al., 2017). A paper closest to ours is Schmalz et al. (2017), who find that increases to house prices as changes of collateral values boost entrepreneurship. Our paper also documents the negative spillovers on new business creation and entrepreneurship to other borrowers due to worse loan terms offered by sensitive banks in low homeownership municipalities.

Finally, we also contribute to the financial integration literature that studies the role of banks in integrating different markets and regions through their internal capital networks (Loutskina and Strahan, 2015; Gilje et al., 2016; Bustos et al., 2017; Cortes and Strahan, 2017; Cunat et al., 2018; Acharya et al., 2019). ${ }^{13}$ The paper that is closest to ours is Chakrabordy et al. (2018). These authors focus on the indirect effects of the pre-crisis US housing boom on the credit supply to firms. They find that banks exposed to housing booms restrict credit to firms, especially if banks and firms are financially constrained. Our paper studies the direct and indirect effects of an exogenous regulatory change that improved the recoverability of real estate collateral in home-backed loans. Also, we can show how credit reallocation affects entry into entrepreneurship and the allocation of labor across regions.

\section{Institutional Setting}

The Brazilian financial sector has historically struggled behind other economies in terms of development and size. For instance, according to the World Bank, credit provided to the private sector in Brazil was approximately $31 \%$ of the total GDP in 2000, which was low compared to China (112\%) and US (162\%) but similar to India (28\%). ${ }^{14}$ Macroeconomic turmoil in the 80s and 90s such as hyper-inflation periods and frequent economic recessions might have curbed the development of financial intermediation. There was also a need for reforms to reduce the cost of lending by creditors. Insecure creditor rights and partially implemented reforms may also explain the underdevelopment by the Brazilian financial sector (Pinheiro, 2003). After the late 90s and 2000s, however, Brazil experienced a credit boom that can be attributed to the macroeconomic stabilization and a series of reforms implemented by the government to give more security to banks and other lenders.

One of these reforms was the implementation of the Real Estate Financial System (Sistema Financeiro Imobiliário) in December 1997 (Law n. 9,514/1997). The main goal was to reduce the housing deficit in Brazil by, among other things, allowing banks and borrowers to use a new and stronger collateral contract. Before this law, parties could only contract under the simple mortgage, in which banks only have a claim over the house pledged as guarantee of the real estate debt. In this setting, if borrowers default, banks would need to file a lawsuit in a local civil court and prove they had a claim over the house due to the mortgage contract. Only after the court recognized the claim that they were allowed to repossess and liquidate the collateral. Due to the inefficient judicial system, this could take a while:

\footnotetext{
${ }^{12}$ According to Iacoviello (2011), housing wealth accounts for about $50 \%$ of total households net worth in the US.

${ }^{13}$ In addition to within-bank integration, Schnabl (2012) provides evidence of interbank propagation of the Russian economic crisis in the 1990s to the Peruvian banking system and economy.

${ }^{14}$ See World Bank's World Development Indicators (WDI) available at the World Bank's website.
} 
the average time a first instance court takes to sentence a case is three years according to the National Justice Council. ${ }^{15}$ Borrowers could also appeal against the decision of first instance, making the collateral recovery even slower and costlier to creditors. A back of the envelope calculation, assuming just the opportunity cost of money of waiting for a court decision, would imply a loss given default of at least $35 \%$ of the outstanding debt's value. ${ }^{16}$ If one also considers appeals to superior courts, other costs attached to the judicial process — such as legal fees and honoraria - and under-maintenance of distressed assets (Campbell et al., 2011), then the loss given default could be substantially higher. ${ }^{17}$

Contrasting to the mortgage contract, in the fiduciary lien, individuals or firms need to transfer their real estate property ownership to the bank as a guarantee of the debt. Instead of having a claim over the house, the bank remains its legal owner until the full debt repayment. The borrower can use or live in the real estate property as long as he/she does not default on the loan. In case of default, the bank must first send a notification to the borrower giving the borrower 2-3 weeks to pay the overdue debt. If not repaid in this time, the bank can evict the occupant and auction the real estate property in less than a month without needing court authorization. This extra-judicial process had a significant impact on the time of collateral repossession by reducing the average time from years to a matter of 1-2 months. Legal fees and the potential under-maintenance problem were also sharply reduced as a result of this law.

The fiduciary lien created in 1997, however, had several drawbacks in terms of effectiveness and scope. ${ }^{18}$ One of them is that the law initially limited the collateral for real estate loans. Since the 1997 law created the real estate financial system to reduce the household deficit in Brazil, the judicial understanding at the time was that the fiduciary lien could only be used as collateral of real estate loans. This was changed in August 2004, when the government approved law n. 10,931/2004 that clarified and consolidated the fiduciary lien contract. The 2004 law, in its article 51, explicitly allowed the use of the fiduciary lien of real estate properties as a guarantee against any debt, not only real estate loans. Therefore, a homeowner could pledge his existing real estate property in exchange for better loan terms, by transferring the title of his/her property to the bank until repayment. For instance, he/she could use it for entrepreneurial reasons such as securing sufficient capital to open a firm or investing in his/her already existing firm. ${ }^{19}$

\footnotetext{
${ }^{15}$ This information was taken from Justiça em Números from the National Justice Council.

${ }^{16}$ The risk-free rate in Brazil at the time was around 15\%, yielding a 3-year discount factor of $65 \%$.

${ }^{17}$ Judicial honoraria can take up to $20 \%$ of total case value, while under-maintenance costs can take up to $15 \%$ of the value of the distressed asset (see Franks et al., 2017, for an analysis of the shipping industry). In this case, the total loss given default can reach up to $60 \%$ of the collateral value after three years.

${ }^{18}$ In terms of effectiveness, superior courts were sometimes preventing banks from stripping individuals of homeownership. This uncertainty was solved in 2002, with the introduction of civil law, whose article 113 introduced the principle of "good faith." This principle, applied to this case, disciplines that those who have given their houses as collateral are assumed to understand the underlying consequences, including eviction from the house due to the non-repayment of the real estate debt.

${ }^{19}$ The housing collateral law also implemented other simultaneous changes orthogonal to the fiduciary lien of real estate assets. First, it created the "patrimônio de afetação", which gave much more security to banks in lending for the acquisition properties that are still in the project stage - i.e., not yet built. In case of bankruptcy of the contractor, the buyer could transfer the remaining construction of his house to another firm, and not lose what already has been built in the bankruptcy procedures. Second, this law also improved the repossession of automobiles given as a guarantee for their acquisition, as analyzed by Assunção et al. (2014). In section 4.5, we provide further evidence that these confounding changes were not explaining our results.
} 
This paper analyzes the effects of the 2004 law, hereafter called "the housing collateral law" on bank lending and access to finance to both homeowners and non-homeowners. ${ }^{20}$

Even after the 2004 reform, there are still some shortcomings of the fiduciary lien in terms of creditor protection and pledgeability. Concerning this paper, these drawbacks should make it more difficult for us to find any positive direct effects of the housing collateral reform of 2004. Nevertheless, for completeness, we discuss these issues next.

One aspect of the fiduciary lien contract that still has room for improvement is due to its non-recourse nature. In the case of default and when the outstanding debt surpasses the value of the house, the bank cannot go after the borrower to recover the residual value of the debt after liquidation. In other words, the acts of repossession and liquidation of the collateral automatically mean that any remaining debt is forgiven. Thus, the fiduciary lien benefits creditors mainly in expansions of the business cycle and housing prices, but not in moments of contraction. This might explain why in the post-financial crisis period home-backed loans lost importance. ${ }^{21}$ Another characteristic that prevents the fiduciary lien from being further beneficial is the fact that the homeowner can only pledge his/her house once at a time. Since the guarantee is the transfer of title of the house, and this can only be done once, the borrower cannot have multiple mortgages on his/her home. This has important implications in the ability of borrowers to pledge the equity of their homes against any debt. In fact, individuals who have recently purchased a house using the fiduciary lien to finance this acquisition could not pledge the equity of its house for other purposes. Since the beginning of 2020, the Brazilian government has been discussing improvements to the fiduciary lien to try to boost it even more and correct for these shortcomings. ${ }^{22}$

\section{Data}

This paper employs two main datasets. First, we take loan-level data from the Brazilian Credit Registry (SCR), a comprehensive restricted-access dataset managed by the Central Bank of Brazil. ${ }^{23}$ Banks in Brazil must report to the central bank all credit contracts that exceed a certain threshold, set to BRL 5,000 in the relevant period for this paper. ${ }^{24}$ Such data allows us to observe loan-level contract terms, such as interest rates, spreads, loan amounts, and other loan contract characteristics for the universe of Brazilian bank credit contracts above the minimum observable amount. In this paper, we consider lending made by commercial banks only, which in June 2004 corresponds to 88 banks, holding 17

\footnotetext{
${ }^{20} \mathrm{An}$ analysis of the direct effects of the 1997 law is left to section A.1. There we show that even though the fiduciary lien was limited in scope to real estate lending and had issues in terms of its effectiveness, we do find that it alleviated the household deficit problem in Brazil.

${ }^{21}$ Because of this issue, we stop the empirical analysis of this paper in June/2007. See Appendix A.4 for a graph with the evolution of home-backed loans in the pre- and post-crisis.

${ }^{22}$ See for instance discussion by government officials about implementing some of these improvements to the fiduciary lien contract at https://valor.globo.com/financas/noticia/2020/01/30/ governo-planeja-facilitar-uso-de-garantias.ghtml.

${ }^{23}$ The tasks of collecting, matching and processing all supervisory data were conducted in secured sites inside the Central Bank of Brazil exclusively by its staff.

${ }^{24} \mathrm{BRL} 1 \approx$ USD 3 at the end of June 2004.
} 
million distinct loan contracts amounting to a total value of BRL 300 billion. With this data, we can measure how local lending conditions change in different municipalities and how banks reallocate credit across different markets as a result of the housing collateral law.

To track employment, we use data from RAIS (Relação Anual de Informações Sociais), a comprehensive restricted-access matched employee-employer administrative dataset from Brazil. The RAIS database records information on all formally employed workers in a given year and is maintained by the Brazilian Ministry of Labour and Employment. All formally registered firms in Brazil are legally required to report annual information on each worker that the firm employs. RAIS includes detailed information on the employer (tax number, sector of activity, establishment size, geographical location), the employee (social security number, age, gender, education), and the employment relationship (wage, tenure, type of employment, hiring date, layoff date, reason for layoff, etc.). We use data from RAIS for the period from 2002-2007 to calculate the number of employees, their wages, and the number of firms in each municipality. We will also be able to follow employees though time, which is going to be necessary for our labor reallocation analysis.

We also gather firms' registry and ownership data from the Receita Federal. ${ }^{25}$ Besides information on firms' location, industry, legal structure and date of opening, we can also identify firms' owners and partners throughout time. All firms in Brazil, including those held privately, are required to report the identity of their owners, partners, and any change in their composition. This information will allow us to measure new business creation as well as entry into entrepreneurship, both used as outcome variables in section 4.3.1.

We also include data from the Brazilian census of 2000 from the Brazilian Institute of Geography and Statistics (IBGE) to measure the number of total and owned households per municipality. Such information is crucial for our identification, described below. We are also able to measure municipalityspecific characteristics, such as the average income with this data.

We also take transaction-level data from the Brazilian Payment Systems, more specifically the Sistema de Transferência de Reservas (STR) and Sistema de Transferência de Fundos (CIP-Sitraf), to construct a measure of cash inflow, i.e., the amount received by each firm due to business transactions with other firms. ${ }^{26}$ This measure will serve as a proxy for firm sales when we talk about the real economic effects to existing firms in section 4.3.2.

Table 1 presents the summary statistics of the variables employed in this paper. We organize the variables based on the section that they are used.

\footnotetext{
${ }^{25}$ Receita Federal is the Brazilian analogous of the US Internal Revenue Service (IRS).

${ }^{26}$ Both STR and CIP-Sitraf are real time gross settlement payment systems that record all electronic interbank transactions in Brazil above a certain limit (set to 1 cent in 2016). The minimum amount that could be transacted electronically was set to $\mathrm{R} \$ 5$ thousand in 2003, $\mathrm{R} \$ 3$ thousand in 2010, $\mathrm{R} \$ 2$ thousand in 2012, $\mathrm{R} \$ 1$ thousand in 2013, $\mathrm{R} \$ 750$ in 2012 , $\mathrm{R} \$ 500$ in 2015, and $\mathrm{R} \$ 0.01$ since 2016. Transactions below the minimum amount would have to be done using cash or cheques and, therefore, would not be recorded in STR/Sitraf. This data also provides information on the exact time of the transaction and identifiers of creditors and debtors.
} 


\section{Empirical Results}

\subsection{Bank Lending: Direct Effects}

This section explains the empirical methodology and reports results for the direct effects of the passage of the housing collateral law in 2004. This law allowed agents to pledge their real estate properties as collateral through a much more creditor friendly contract. As a piece of initial evidence, Figure 1 plots the evolution of loans with real estate collateral used for non-real estate purposes only around the passage of the housing collateral law in August 2004. This graph shows that, before the law was passed, there appeared to be no significant deviation from its simple linear trend. After August 2004, however, these loans experienced a sharp increase, going to approximately $60 \%$ above of its linear trend in June 2007. This significant increase in loans with real estate collateral is a suggestive evidence that the 2004 law led to higher credit market access and possibly better loan terms.

While the graphical representation in Figure 1 hints at a positive effect of the housing collateral law on bank lending, a concern would be that home-backed loans increased in this period for other motives, such as higher demand for this type of credit or changes in house prices that are unrelated to the collateral reform. Also, this reform directly concerned homeowners, so in theory, they should be the ones to benefit from it. We deal with these concerns by comparing bank lending outcomes in municipalities with different degrees of homeownership around 2004 in a differences-in-differences (DiD) setting. ${ }^{27,28}$ The identification assumption is that, in the absence of the housing collateral law, bank lending would have kept increasing at a similar trend in municipalities with different homeownership rates. We run the following regression to measure the direct effects of the housing collateral law:

$$
y_{m b t}=\alpha_{m b}+\alpha_{b t}+\beta \cdot \text { Homeownership } m \cdot \text { Post }_{t}+e_{m b t},
$$

where $m$ refers to a municipality, $b$ to a bank, $t$ to year. The outcome variable $\left(y_{m b t}\right)$ is a bank-outcome variable, such as the credit balance or the interest rate at the municipality-bank-year level. The variable Post $_{t}$ is a dummy equal to 1 after 2004 and zero otherwise. We calculate homeownership at the municipality level - Homeownership ${ }_{m}$ — as the ratio between the number of owned households and the number of total households. This information comes from the Brazilian Census of 2000 (pre-reform) that is collected by the IBGE. The main coefficient of interest is $\beta$, which measures how much bank outcomes change around the passage of the housing collateral law in municipalities with different ex-ante homeownership levels. We also add municipality-bank fixed effects to control for any timeinvariant factor explaining our results at the branch level, and bank-year fixed effects to control for any bank-specific trends in lending around the passage of the law that might be driving our results.

\footnotetext{
${ }^{27}$ This identification strategy is similar to the one by Schmalz et al. (2017), who also use the homeownership across different French regions to identify the effect of changes in the real estate collateral value on borrowing.

${ }^{28}$ In fact, it is common for the literature to divide agents into groups that reflect the potential for treatment. Vig (2013), for instance, classifies firms according to the ratio between tangible and total assets when analyzing the effect of regulatory changes that increased the ability of secured creditors to recover the collateral in case of default. Similarly, Campello and Larrain (2016) use movable capital ratio to identify the treatment effect of a law that allowed the use of machinery and equipment as collateral.
} 
We take information as of June 2004 — just before the passage of the law — and June $2007 .{ }^{29}$ With just two time periods, we can take the difference of equation (1) across time, which will lead to

$$
\Delta y_{m b}=\alpha_{b}+\beta \cdot \text { Homeownership }{ }_{m}+u_{m b}
$$

Table 2 presents the results of this specification for outcomes related to home-backed loans (columns I to IX) and total credit of bank $b$ in municipality $i$. Home-backed loans are defined as loans to individuals secured by real estate collateral and used for non-real estate purposes. Total credit aggregates all loans to both individuals and firms in each bank and municipality. All of our results in this table and following tables, we normalize the main explanatory variables by dividing them by their standard deviation.

We find that banks expand credit supply in areas with higher homeownership after the reform. A one standard deviation increase in homeownership is associated with a $20.4 \%$ increase in home-backed loans (column I) and a 27 basis points decrease in the interest rate charged on these loans (column IV) after 2004. The simultaneous increase in credit and decrease in the interest rates charged suggest that banks expand their credit supply to areas with higher homeownership after the housing collateral reform in 2004.

Not only home-backed loans but also overall credit in municipalities with higher homeownership also increases after the reform. A one standard deviation higher homeownership is associated with an $8.7 \%$ increase in total bank credit (column X). More importantly, however, is that most of the increase in total credit is due to home-backed loans. In column VII, we show that the proportion of homebacked loans to total credit increases by $0.9 \%$ for municipalities with a one standard deviation higher homeownership. Interest rates charged on these loans do not change significantly.

One concern with this strategy is that municipalities with different degrees of homeownership might also differ in other characteristics not taken into account in the specification above. Panel A of Figure 2 shows that homeownership is strongly spatially correlated. Municipalities in the North and Northeast of Brazil - less economically developed regions - have higher homeownership while municipalities in the mid-south have the lowest. To address these concerns, we compare municipalities within the same mesoregions. Such strategy compares, on average, 40 municipalities. ${ }^{30}$ Panel B of Figure 2 shows the same map as before but now subtracting the average of homeownership observed within each mesoregion. The distribution of treated and control counties across the country after this normalization is much more dispersed, approaching the treatment of being randomly assigned within each region.

In Table 2, we show additional results where we now compare municipalities within the same geographical region. We achieve this by adding mesoregion fixed effects in equation (2). Home-backed loans increase by $15.1 \%$ for close-by municipalities with a one standard deviation higher homeownership (column II). Again most of this increase is driven by home-backed lending: total credit increases

\footnotetext{
${ }^{29}$ We perform this to alleviate concerns of auto-correlation of the residuals (Bertrand et al., 2004). This assumption is not crucial and results with robustness tests using other periods are available upon request.

${ }^{30}$ Mesoregions are groups of municipalities close to each other that share common social, economic, and demographic characteristics. It is a statistical subdivision of Brazilian states.
} 
by $10.3 \%$ (column V), and the proportion of home-backed loans increases by $1.1 \%$ (column VIII). Interest rates charged on home-backed loans and total credit both decrease by one percentage point after 2004 in municipalities with a one standard deviation higher homeownership rate (columns XI and XIV). These estimations confirm that the 2004 reform encouraged home-backed lending since bank credit supply in areas with higher homeownership.

We further saturate the regression by adding the interaction between income per capita terciles, region, and bank fixed effects. Homeownership is negatively correlated with income per capita. In fact, the correlation between these two variables in the data is $-49 \%$. While controlling for region fixed effects might absorb some of this correlation, we go further and compare municipalities in the same region and income per capita, but with different homeownership. The results for this specification are presented in Columns III, VI, IX, XII, and XV. Again, results are consistent with the view that the 2004 reform improved access to financing in areas with higher ex-ante potential of treatment.

We alleviate the concern that there are unobservable factors that might be correlated with homeownership and explain our results by showing in Figure 3 a graph of the differences-in-differences coefficients around August 2004, when the law was introduced. In the quarters before August 2004, home-backed lending appears to be growing at similar rates in municipalities with different homeownerships. ${ }^{31}$ Only after the reform in September 2004, bank lending appears to react and increase in municipalities with higher homeownership. Therefore, any alternative explanation for the direct effects of the housing collateral law would have to explain why credit only reacts significantly from September 2004 onwards.

\subsection{Bank Credit Spillovers}

The previous section presented evidence that the 2004 housing collateral law led to an increase in credit availability in municipalities with higher homeownership, consistent with the intention of the government in enacting this reform in the first place. This section asks whether there were unintended consequences of this reform to borrowers located in areas with low homeownership. In particular, we ask whether banks' decision to allocate credit after the housing collateral law in the economy resulted in changes in lending to even those borrowers who were not initially affected by the law.

The existence and direction of credit spillovers as a result of stronger creditor rights are ambiguous. A traditional view in the literature on law and finance would say the average borrower benefits from stronger creditor rights, and no one else is worse off as a result. However, when we look at the problem from the banks' perspective, and assume there are limits to raising external finance, the decision to lend to a particular borrower might also depend on the expected return of lending to other borrowers.

Applied to our setting, changes in credit conditions to homeowners can also be propagated to others. The direction of the spillover effect depends on two opposing channels. On the one hand, lending to homeowners becomes safer after housing collateral law, and thus, lending to non-homeowners is relatively more expensive in the bank's perspective. As a result, banks reduce credit supply to the latter to finance increase in lending to the former. On the other hand, stronger creditor rights might

\footnotetext{
${ }^{31}$ The parallel trends assumption is a necessary condition for the diff-in-diff method to be valid.
} 
reduce the overall riskiness of banks' credit portfolio, which should reduce their risk-weighted assets and thus relax banks' capital constraints. As a result, banks might even be able to increase lending to non-homeowners, given the decrease in riskiness in home-backed loans to homeowners. Which of these effects dominates is an empirical question that we examine next.

Our empirical strategy to document whether banks reallocate credit across regions in Brazil compares lending made by banks with different sensitivity to the housing collateral law before and after its passage in a DiD setting. We define bank $b$ 's sensitivity to the law as its fraction of credit portfolio located in municipalities with high homeownership, i.e., above the national median:

$$
\text { Bank Sensitivity }_{b}=\frac{\sum_{m \in \text { High Homeownership }} \text { Credit }_{b m}}{\sum_{i} \text { Credit }_{b m}},
$$

where bank $b$ 's credit to municipality $m$ is measured in June 2004, the quarter before the reform was approved. This variable varies from zero, i.e., the bank is not exposed to these municipalities, to one, i.e., all of bank $b$ 's credit portfolio is in high homeownership municipalities.

Changes in credit, however, might be due to either shifts in credit supply or demand. Since the purpose of this paper is to identify changes in credit supply to initially unaffected borrowers, we propose an econometric specification that compares lending by banks with different sensitivity to the housing collateral law in the same low homeownership municipality. This way, we control for any variation in local demand for credit and only identify how credit supply from more sensitive banks shifts when compared to less sensitive banks as in Khwaja and Mian (2008).

The main DiD specification — already in first differences — is defined as follows:

$$
\Delta y_{m b}=\alpha_{m}+\gamma \cdot \text { Bank Sensitivity }{ }_{b}+u_{m b}
$$

where $m$ refers to a municipality in the lower median of homeownership, and $b$ to a bank. $\Delta y_{m b}$ is the growth of a credit outcome variable at the municipality-bank level. In our specifications, the outcome variable will be either bank lending or the charged interest rates on these loans. Municipality fixed effects $\left(\alpha_{m}\right)$ control for any common changes at the local level. The interpretation of the DiD coefficient $(\gamma)$ is the average change in credit granted, and interest rates charged to the same municipality of a bank with a one standard deviation higher sensitivity to the housing collateral law, as defined in equation (3).

Table 3 presents the results from estimating equation (4). In columns I and II, we find that banks with a one standard deviation higher sensitivity decrease the amount lent in municipalities with low homeownership by $8.8 \%$ and increase the interest rates charged on their loans by almost 11 basis points, even though not statistically significant at the $10 \%$ level. This means that the credit supply of more sensitive banks decreases in low homeownership municipalities and that banks substitute credit away from low to high homeownership municipalities after the housing collateral law.

A possible concern with the results presented above is that banks with different sensitivity might be 
systematically different from one another, and therefore we might be picking up these different characteristics and not the sensitivity to the housing collateral law. Columns III and IV of Table 3 present specifications where we add bank controls, such as bank size dummies, liquidity ratio, capital ratio, and bank profitability. Results remain qualitatively unchanged. A one standard deviation increase in bank sensitivity is associated with a drop of $6.6 \%$ in credit and an increase of 36 basis points in interest rate, or $1.6 \%$ of its unconditional mean.

We provide further evidence that this credit reallocation was due to the housing collateral law by analyzing the differences-in-differences effect in the quarters around the passage of the law in Figure 4. As the Figure shows, banks with higher sensitivity to the law did not restrict credit in the first two quarters of 2004, when compared with 2003. This evidence suggests that the trends in lending of banks with different sensitivity were parallel before the passage of the law. Only after September 2004, the marginal effect becomes negative and statistically significant, which is consistent with the credit reallocation from low homeownership areas starting when the housing collateral law was passed.

While the previous specifications analyzed how credit changed at the local municipality level, a concern is that more vulnerable borrowers are connected to banks with higher fraction of their portfolio in high homeownership areas to begin with. If this is the case, we would be overestimating the decrease in credit supply of these banks, since the overall effect would also measure a latent characteristic of these borrowers that make them more likely to experience a decrease in borrowing. For instance, after the banks start reallocating credit away from low homeownership municipalities, borrowers vulnerable to local economic conditions might lower their demand for credit. If these borrowers are also more likely to be connected to banks sensitive to the reform, this will lead to an overestimation of the reallocation effects. This bias is not solved by controlling for changes in aggregated local credit demand, as in Table 3. Also, this concern would still be valid even if the parallel trends assumption holds as it is the case in Figure 4.

To solve this problem, we compare lending made by different banks to the same borrower located in low homeownership municipalities. Banks can reallocate credit away from individuals and firms in these areas. We initially focus on the effect on firms. ${ }^{32}$ From the universe of firms borrowing from commercial banks in Brazil and with information in the Credit Registry, we take all firms with at least one employee and that borrowed from more than one bank as of June 2004. This leaves us with more than 100,000 distinct firms in our sample. The median firm in the sample is an entrepreneurial firm with five employees, which in areas with low homeownership might be owned by non-homeowners.

In columns I and II of Table 4, we find that banks with a one standard deviation higher sensitivity decrease the amount lent to firms in municipalities with low homeownership by $5.8 \%$ and increase the interest rates charged on their loans by almost 25 basis points. When controlling for bank characteristics, results still point out to a restriction in credit supply. The total amount lent decreases by $3.7 \%$ and the interest rate charged on these loans increase by 47 basis points, or $1.7 \%$ of its unconditional mean. Overall, controlling for within-firm changes in credit demand makes our coefficients slightly smaller than in the local municipality specification. However, the finding that banks reallocate credit

\footnotetext{
${ }^{32}$ We show that similar results when looking at individuals borrowing from multiple banks in a robustness test section.
} 
from borrowers located in low homeownership municipalities remains the same.

\subsubsection{Credit Reallocation and Bank Funding Constraints}

This section asks whether financial and regulatory frictions are factors that might exacerbate this reallocation. Banks with low equity capital, for instance, might be unable to increase their leverage due to binding regulatory capital requirements. Similar reasoning applies to banks with not enough cash or other investments that are easy to liquidate in the short run. To test this hypothesis, we interact our bank sensitivity measure with bank equity to total assets ratio - a measure of bank capitalization and bank non-credit assets to total assets ratio - a measure of bank liquidity.

Table 5 presents the results of this specification. We standardize all variables, i.e., we subtract their means and divide the differences by their standard deviations. In terms of magnitude, when capital ratio and liquidity ratio are both at their average values, higher bank sensitivity to the law leads to a $2.7 \%$ decrease in credit and 15 basis points decrease in the interest rate charged on their loans. A one standard deviation increase (decrease) in capital ratio leads to a $2.4 \%$ higher (lower) credit in these areas and a lower (higher) 1.239 percentage points in the interest rate charged. Similarly, a one standard deviation increase (decrease) in liquidity leads to a $2.7 \%$ increase (decrease) in credit and a decrease (increase) in 82 basis points in the interest rate charged. Overall, banks that are more financially constrained, either in terms of low capital ratio or low liquidity, are the ones that restrict credit the most in low homeownership municipalities.

\subsubsection{Results with Different Aggregation Levels}

This section provides further evidence that our previous results indeed document a credit reallocation away from borrowers in low homeownership municipalities. There are at least two concerns with stating that more sensitive banks are reallocating credit. The first is that other banks might pick up the slack of their more exposed counterparts and increase lending to firms that experience a sharp credit restriction. This would mean that credit by the control banks in our previous specification might increase as a result, mitigating in part the cut in lending in areas with low homeownership. Thus, when we compare lending by banks with different sensitivity to the law, we might be overestimating the true magnitude of the credit reallocation to the firm. The second concern is related to the extensive margin: firms might also start borrowing from new banks to compensate for the harsher loan terms of sensitive banks. Since our previous specifications compare firm borrowing from existing bank connections, our results are not taking this extensive margin channel into account.

We propose to deal with these concerns by running a similar specification as before but with all the variables aggregated at the firm-level. We still keep firms that had multiple bank connections in June 2004 and with at least one employee. ${ }^{33}$ The drawback of this specification is that we would not be

\footnotetext{
${ }^{33}$ Results of this specification are robust to also considering firms with single bank connections as of June 2004. Since we do not control for firm-year fixed effects in this specification, these firms would be considered in the regression. See table 16 in the robustness section.
} 
able to control for firm-specific changes in credit demand to identify shifts in bank credit supply as in the Khwaja and Mian (2008) specification in section 4.2. To the extent that credit demand is highly correlated for firms in the same municipality and industry (local industry), then the second-best would be comparing borrowing by firms in the same local industry but with different average levels of bank sensitivity around the passage of the law. If credit is being fully compensated by less sensitive banks or new bank connections, then we should not observe differences in borrowing by similar firms with different ex-ante levels of bank sensitivity.

We construct the average of bank sensitivity for each firm, by aggregating each firm $i$ 's creditor bank sensitivity to the law with respect to the credit that the firm takes from bank $b$ as of Jun/2004, i.e.:

$$
\text { Bank Sensitivity }_{i}=\frac{\sum_{b} \text { Credit }_{b i} \cdot \text { Bank Sensitivity }_{b}}{\sum_{b} \text { Credit }_{b i}}=\sum_{b} M S_{b i} \cdot \text { Bank Sensitivity }_{b},
$$

in which $M S_{b i}$ is the market share of credit granted by bank $b$ to firm $i$. We then employ this measure in the firm-level equation below:

$$
\Delta y_{i}=\alpha_{m k}+\gamma \cdot \text { Bank Sensitivity }_{i}+u_{i}
$$

where $\Delta y_{i}$ is the growth in firm $i$ outcome variables, such as growth in log bank credit and growth in interest rates charged. We add municipality-industry $\left(\alpha_{m k}\right)$ fixed effects. Note that this equation is equivalent to equation (4) but at the firm-level.

Panel A of Table 6 shows that the results are qualitatively the same as in the disaggregated analysis of Table 4. In columns I and II, a one standard deviation increase in Bank Sensitivity ${ }_{i}$ leads to a $10 \%$ decrease in total bank credit in the municipality and a 1.30 percentage points increase in the interest rate charged. These findings rule out the concern that the results would be significantly weaker or even not statistically significant anymore in the aggregate. If anything, coefficients appear to be slightly stronger in this specification when compared to Table 4. In columns III and IV, we add fixed effects of municipality interacting with industry, so as to compare firms in the same local industry, but connected to banks with different sensitivity with the law. Results still show a reallocation: credit decreases by $5.2 \%$, while interest rate charged increase by 0.98 percentage points. Finally, in columns V and VI, we further saturate the fixed effects by comparing firms in the same local industry, the same age and size groups. The size measurement is based on the official classification of Brazilian authorities based on the number of employees of the firm. ${ }^{34}$ Results are qualitatively and quantitatively unchanged. Overall, the credit reallocation in these areas was not restricted to a particular bank but also applied to overall aggregate lending across all banks in these municipalities.

A similar concern, however, is that firms connected to less sensitive banks are somehow benefiting from local industry competitors experiencing lower bank credit supply. If this is the case, we would

\footnotetext{
${ }^{34}$ Firms are divided into size groups based on the number of employees and whether they are from tradable or nontradable sectors. According to SEBRAE, firms in the manufacturing sector are considered micro-firms if they have at most 19 employees; small are those with 20 to 99; medium, 100 to 499; and large with more than 500 employees. Non-tradable firms, such as those from services and retail, are micro-sized firms if they have at most nine employees; small firms have 10 to 49 employees; medium-size firms, 50 to 99; and large firms are those with at least 100 employees.
} 
have a similar overestimation problem as in the one addressed above. To address this issue, we compare borrowing by firms in the same local industry. As a solution, we now aggregate variables at the local industry level. If firms can increase borrowing at the same rate that credit is restricted to competitors, then we should not observe differences in borrowing for local industries connected to banks with different sensitivity to the housing collateral law. We construct the average of bank sensitivity for each local industry as a weighted average of the bank sensitivity at the firm-level as of Jun/2004, i.e.:

$$
\text { Bank Sensitivity }_{m k}=\frac{\sum_{i} \text { Credit }_{i m k} \cdot \text { Bank Sensitivity }_{i}}{\sum_{i} \text { Credit }_{i m k}},
$$

where $i$ refers to a firm, $m$ refers to the municipality where this firm is located, $k$ to the industry it belongs to. We then employ this measure in the local industry level equation below:

$$
\Delta y_{m k}=\alpha_{k}+\gamma \cdot \text { Bank Sensitivity }{ }_{m k}+u_{m k}
$$

Panel B of Table 6 alleviates again concerns of overestimation. Columns I and II show that a one standard deviation increase in bank sensitivity at the local industry level leads to an $8.7 \%$ drop in credit and a 1.62 percentage points increase in interest rate. In columns III and IV, we compare local industries of the same sector across Brazil. Results are virtually identical as before. When we compare local industries in the same region - columns V and VI - the magnitude of the coefficients drops slightly to a drop of $7.5 \%$ for credit and an increase of 1.29 percentage points in interest rates but both coefficients still significant and similar to previous specifications.

\subsubsection{Credit Reallocation and Heterogeneous Effects Across Firms}

We have shown that sensitive banks appear to restrict credit to the average firm and that this drop is not compensated by increased borrowing from other banks. This section asks whether the credit restriction affects some firms more than others and what are the possible reasons for this. Financially constrained and informationally opaque firms are possible candidates for this different treatment. Informational asymmetry explains why opaque firms might be more affected by this credit reallocation through at least two different channels. The first one is that sensitive banks might restrict credit, especially to those firms in which acquiring information is harder. The second channel is an extensive margin argument: opaque firms might find it difficult to substitute sensitive banks' credit with other types of financing since potential new creditors might be unwilling to start new relationships with those firms.

We take data on firms' age and size from Receita Federal and RAIS as of June 2004 to test these hypotheses. These two variables are correlated to firm opaqueness by several papers in the literature (Petersen and Rajan, 1994, 1995; Berger and Udell, 1995). It is difficult to access the creditworthiness of these firms: young firms do not have a long history that banks can base their screening process on, and small firms might not release credible financial statements, if any. We measure firm age as of June 2004 and classify firms into three groups: (a) with age between 0 and 5 years; (b) 5 and 20 years; and (c) more than 20 years. We measure firm size based on the number of employees each firm had in 
December 2003 using data from RAIS. Firms are divided into two classifications based on the official government classification of large and small firms.

To test the first channel, we compare lending made by different banks to the same firm as in equation (4). However, we now interact our bank sensitivity measure with dummy variables of firm age and firm size. Results with firm age are presented in columns I and II of Table 7, Panel A. Younger firms indeed suffer more from the reallocation of credit from sensitive banks. Firms created less than five years before the reform experience a drop of $5.7 \%$ in credit (column I) and an increase of 61 basis points in the average interest rate (column II) from banks one standard deviation more sensitive to the housing collateral law. This magnitude and statistical significance of this effect are smaller for firms with more than 5 years and less than 20 years of age since credit drops by $3.5 \%$, and interest rates increase by 57 basis points with a one standard deviation increase in bank sensitivity. In columns I and II of Table 7, Panel B, we show that the same holds for smaller firms. Small firms experience a drop of $4.5 \%$ in credit by banks with a one standard deviation higher Bank Sensitivity, while large firms do not appear to suffer from this reallocation.

Even though sensitive banks restrict credit the most to opaque firms, this would not be a concern to these firms if they could easily substitute sensitive bank loans and borrow from other banks. To test this hypothesis, we aggregate bank credit at the firm-level, similarly as in equation (6) but now interacting

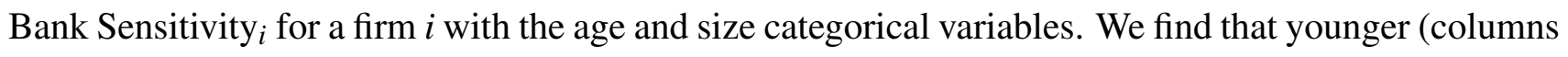
III and IV, Panel A of Table 7) and smaller firms (columns III and IV, Panel B of Table 7) do not manage to compensate for the reduced credit by sensitive banks. If anything, coefficients in columns III and IV of Panels A and B of Table 7 are slightly larger in magnitude for younger and smaller firms. Older and larger firms' borrowing, however, does not seem to be significantly affected, suggesting that they can substitute sensitive banks' credit and borrow more from other banks to compensate for the credit restriction. Overall, the credit reallocation affected mostly younger and smaller firms, who cannot easily substitute credit.

\subsection{Real Economics Effects}

After showing that the housing collateral law led to a credit reallocation from low to high homeownership municipalities, this section provides evidence on the real economic consequences of the housing collateral law to homeowners and non-homeowners. There is an extensive literature that discusses the positive effects of relaxing financial constraints on the overall economic development (King and Levine, 1993; Beck et al., 2005), firms' hiring, and investment (Campello and Larrain, 2016; Ponticelli and Alencar, 2016; Calomiris et al., 2017), and the entry into entrepreneurship (Hurst and Lusardi, 2004; Adelino et al., 2015; Corradin and Popov, 2015; Schmalz et al., 2017). Nevertheless, there is limited evidence on the possible negative spillovers that may accompany these positive effects due to a reallocation of loanable funds within the economy. We present evidence of the effects of credit reallocation on entrepreneurship (section 4.3.1), employment, wages and firm sales (section 4.3.2), and local economic activity (section 4.3.3). 


\subsubsection{Entry into Entrepreneurship}

In this section, we estimate the direct and spillover effects of the housing collateral law on entrepreneurship. The literature on entrepreneurship has found that relaxing the financial constraints of households, for instance, when housing collateral value increases, has the effect of boosting entrepreneurship and the creation of new firms (Evans and Leighton, 1989; Evans and Jovanovic, 1989; Schmalz et al., 2017). While the housing collateral law may have promoted access to finance by homeowners, and thus spurred the opening of new business and entry into entrepreneurship, an unintended consequence of this law might have been the decrease in entrepreneurship of non-homeowners due to a restriction in credit supply to them. We have previously documented that borrowers in low homeownership municipalities experience a credit restriction by banks. Now, we ask whether this restriction also had an impact on the creation of new firms.

We measure entry into entrepreneurship and firms creation at the municipality level using information on firms' opening date as well as the identity of firms' owners from Receita Federal. This data is an owner-firm matched dataset that also provides information on the date of entry of each firms' proprietors and partners. It contains information on more than 17 million individuals who are partners or firm-owners in Brazil.

For our first test, we consider only firms that were recently created - i.e., at least three years since creation date - and that have at least one employee. We calculate the number of distinct young firms and the number of proprietors and partners of each of these firms. We also use the Credit Registry data to observe bank lending to firm-owners of recently created firms. Note that because we are only considering young firms, we cannot follow the same firm from before until after the reform of 2004. We aggregate these variables at the municipality level and compare the entry into entrepreneurship and firm creation in municipalities with (i) different homeownership rates; and (ii) low homeownership but with different average bank sensitivity levels. More specifically, we are interested in determining how the number of young firms changes in these municipalities, as well as the number of distinct firm-owners - i.e., entrepreneurs. Finally, we examine how lending to these owners responds in these different municipalities.

Table 8 shows in columns I to III that entry into entrepreneurship indeed increases as a result of the housing collateral law. Owners of newly founded firms increase their home-backed borrowing by $48 \%$ with a one standard deviation increase in homeownership. Besides, the same one standard deviation increase in homeownership is associated with $16.4 \%$ and $13.5 \%$ higher number of entrepreneurs and new firms, respectively, after the reform. The higher pledgeability of real estate collateral seems to have increased credit access to previously constrained potential entrepreneurs and allowed them to pursue their entrepreneurial projects.

Nevertheless, columns IV to VI show the adverse effects on entrepreneurship due to the credit reallocation. We find that a one standard deviation higher Bank Sensitivity ${ }_{m}$ in municipalities leads to a $49.6 \%$ drop in total borrowing by owners of young firms, a $18.8 \%$ reduction in the number of firm-owners, and a 3\% drop in the number of firm openings. Overall, the credit restriction in low homeownership 
municipalities also strongly discourages entrepreneurial activity in these areas.

\subsubsection{Firm Performance}

Last section presented evidence of the credit reallocation on the creation of new firms. This section analyzes how it affects the performance of existing firms. More specifically, we analyze the effect of the credit reallocation on firm sales, employment, and average wages paid to workers. We take information on employment from RAIS, which is an employee-employer matched dataset with information on the universe of formal labor contracts in Brazil, including information on wages. We also create a proxy of firm sales by calculating the total amount received by each firm in the Brazilian Payments System. This system records every inter-bank transaction in Brazil.

First, we regress the growth of these firm-level variables from 2003 to 2007 against homeownership of the municipality where they are located in. Columns I to IV of Table 9 present the results of the direct effect of the housing collateral law on cash inflow, employment, and wage, respectively. We find that firms located in municipalities with higher homeownership experience a $1.2 \%$ increase in cash inflow, employment also increases by $0.8 \%$ and average wage is $1.3 \%$ higher. These results point to either higher labor demand or the hiring of skilled employees by these firms. In column IV, we regress the within individual growth in wage. We find that wages to the same worker increase by $0.7 \%$ when homeownership increases by one standard deviation. This result indeed suggests an increase in labor demand.

In addition to the positive effects of the housing collateral law to firm performance, we now look at firms in low homeownership municipalities and connected to banks with different sensitivity measures. ${ }^{35}$ Columns V to VIII of Table 9 show that firms connected to more sensitive banks experience a drop in cash inflow by $1.8 \%$, employ $2.3 \%$ fewer workers and pay $0.4 \%$ lower wages to the average worker, and $0.1 \%$ lower wages to the same worker. Overall, these firms seem to experience lower performance, and lower demand for labor since both employment and wages seem to decrease for firms connected to banks with high sensitivity to the reform. Overall, the spillover results usually have the opposite sign to what was found for the direct effects. In addition to changes in credit and entrepreneurship, there are also costs in terms of existing firms' performance of stronger creditor protection.

\subsubsection{Local Performance}

Besides the effects on firms' performance, we are also interested in determining the effects on local economic growth. We take data on municipality GDP, calculated by IBGE, and regress it against our homeownership variable at the municipality level and a weighted average of bank sensitivity for each municipality.

\footnotetext{
${ }^{35}$ In this specification, firms that did not borrow from any bank pre-2004 are also considered, and their bank sensitivity measure is set to zero.
} 
Column I of Table 10 points out a boost to the economic activity of high homeownership municipalities after the reform. Local GDP increases by 1.1\% from 2003 to 2007 in municipalities with a one higher standard deviation in homeownership. Columns II presents a similar specification for low homeownership municipalities with different average bank sensitivitys. A one standard deviation higher bank sensitivity is associated with a $2 \%$ drop in local GDP. As with firm performance, the credit reallocation also appears to generate heterogeneous effects at the local level.

\subsection{Real Reallocation: Migration of Labor}

Besides the different effects on local economic performance, this paper asks whether the credit reallocation triggers a real redistribution of resources across Brazilian municipalities. More specifically, we examine whether workers change their jobs from low to high homeownership municipalities, as banks also move credit away from the former and increase to the latter areas as a result of the housing collateral law.

We employ data on the universe of labor contracts from RAIS in the 2002-2007 period to measure the work migration flow among Brazilian municipalities both before and after 2004. To measure migration flows, we count the number of employees in each municipality at the beginning of 2002 and 2005 before and after the law, respectively - that were working in another municipality two years after, i.e., at the beginning of 2004 and 2007, respectively. We use this information to calculate the migration flow from a municipality (origin) to another (destination) of these years (Migrants ${ }_{\text {orig } \rightarrow \text { dest }}$ ). Similarly, as in the previous section, we employ a differences-in-differences approach by comparing these migration flows before and after the housing collateral law in municipalities with different homeownership and average bank sensitivity to the reform.

We first ask whether there is more migration from areas with low homeownership vis-a-vis areas with higher homeownership. We have seen that areas with higher homeownership experience an increase in credit supply and better local economic performance as a result of the housing collateral law. Thus, we test whether more workers are likely to leave low homeownership municipalities to find jobs elsewhere. We test this hypothesis by regressing the log of migration flows against a dummy equal to one if the municipality at the origin is in the lower median of homeownership. In other words, we run the following regression:

$$
\Delta \ln \left(\text { Migrants }_{\text {orig } \rightarrow \text { dest }}\right)=\alpha_{\text {dest }}+\gamma \cdot \text { Low Homeownership } \text { orig }+u_{\text {orig,dest }},
$$

where orig refers to the origination municipality and dest to the destination. The dependent variable is the growth of net migration flows between 2005-2007 and 2002-2004 in each origination-destination municipality pair. Low Homeownership ${ }_{\text {orig }}$ is a dummy equal to 1 for origination municipalities in the lower median of homeownership. We add a destination municipality fixed effect $\left(\alpha_{\text {dest }}\right)$ to identify the changes of emigration at the origin municipality and control for any time-varying factor that explains immigration at the destination level. The coefficient of interest $-\gamma-$ measures to what extent workers emigrate from low vis-a-vis high homeownership municipalities to the same destination municipality. 
See Panel A of Figure 5 for a visual design of our benchmark empirical specification.

Columns I and II of Table 11 present the results of this specification. In column I, one can see that migration increases by 3\% in low homeownership municipalities in 2005-2007 when compared with 2002-2004. In other words, if before 2004 there were 100 workers emigrating from a low homeownership municipality to another municipality, after 2004 there are 103 workers migrating from the former to the latter. In column II, we also add fixed effects on the mesoregion of the municipality at the origin of the migration. This specification then compares migration from municipalities in close geographical but with different homeownership rates, as plotted in Panel B of Figure 5. Coefficients are quantitatively unchanged. This result is evidence that the worsening of local economic performance in low homeownership areas as a result of the credit restriction has made employees look for employment elsewhere.

A natural follow up question is whether this migration is stronger when the destination municipality has higher homeownership, i.e., when it benefited from the housing collateral law. If this is the case, high homeownership municipalities might not only benefit from increased credit supply at the expense of lower credit elsewhere but also labor would be reallocated across these areas. To test this hypothesis, we add the interaction homeownership at the destination and low homeownership to equation (9).

Columns III and IV of Table 11 show that the migration of workers from low homeownership municipalities is indeed higher when the destination has a higher homeownership rate. Column III uses destination municipality fixed effect, and column IV also adds regional fixed effects or the origin. Regardless of the specification, a one standard deviation increase in homeownership at the destination increases migration from low homeownership origin areas by $0.3 \%$. Besides the reallocation of credit, there is also a reallocation of workers that move from low to high homeownership areas.

Finally, since we have found that credit restriction is proportional to the bank sensitivity to the high homeownership municipalities, we expect the migration flow to be stronger in municipalities with a higher presence of sensitive banks. We test this hypothesis by interacting the low homeownership dummy with the Bank Sensitivity measure at the origin municipality to equation (9).

Results for this specification are presented in columns V and VI of Table 11. We standardize the Bank Sensitivity measure by demeaning it and dividing it by its standard deviation. The interacted coefficient is positive and significant in both columns. A one standard deviation increase in bank sensitivity leads to a $1.5 \%$ increase in the number of migrants from low homeownership municipalities. This number slightly increases to $1.8 \%$ when we compare migration from municipalities in the same mesoregion. These results point out that the higher the credit restriction in low homeownership areas, the more relevant is the emigration from these areas.

\subsubsection{Migration of Labor and Home-Backed Loans}

There is evidence that workers migrate from low to high homeownership municipalities after the housing collateral law. The attractiveness of these destination municipalities to workers, however, might be a direct consequence of the higher access to bank credit — such as increased home-backed loans — or 
due to the stronger real economic activity that this increased credit availability has brought upon these municipalities. To differentiate between these two channels, this section asks whether workers are migrating from low homeownership municipalities to firms whose owners are taking up home-backed loans.

To perform this test, we first identify which firm-owners are taking up home-backed loans in either June 2004 or June 2007. We then observe how many workers were hired by these firms in 2004 and 2007 but were working in a different municipality in 2002 and 2005 respectively, using the RAIS dataset. Finally, we aggregate this information at the destination-origination municipality pair both before and after the reform. To gauge the importance of this migration flow due to the housing collateral reform, we employ as dependent variable the ratio of this home-backed migration flow and the total migration flow from the pair of municipalities, as follows:

$$
\Delta\left(\frac{\text { Home-Backed Migrants }}{\text { Migrants }}\right)_{\text {orig } \rightarrow \text { dest }}=\alpha_{\text {dest }}+\gamma \cdot \text { Low Homeownership } \text { orig }+u_{\text {orig,dest }} .
$$

Results of this specification are presented in Table 12. Columns I and II show that workers from low homeownership municipalities are more likely to leave their municipalities to work in firms whose owners are borrowing through a home-backed loans. The fraction of migrants to these firms increases by $0.6 \%-0.9 \%$ around 2004. Columns III and IV show that this effect is stronger when the destination municipality has higher homeownership. A one standard deviation higher homeownership at the destination is associated with a $0.4 \%$ further increase this migration flow ratio. This result is consistent with the existence of a higher number of entrepreneurs that can borrow against their real estate properties, and therefore attract workers from lower homeownership municipalities. Finally, this migration seems to be stronger when there is a higher presence of sensitive banks at the origin municipality (columns $\mathrm{V}$ and VI). A one standard deviation increase in Bank Sensitivity leads to a $1.4 \%$ higher fraction of home-backed migrants to total migrants.

\subsection{Robustness tests}

\subsubsection{Housing Collateral Law and Court Congestion}

This paper studies a law that has strengthened creditor protection by allowing homeowners to pledge their houses against a much more comprehensive collateral contract, through the consolidation of the fiduciary lien contract. A significant advantage of this contract is its extra-judicial execution and liquidation given default. In other words, the fiduciary lien allows creditors, in case of default, to consolidate ownership over the collateral without having to go to courts. Therefore, if the results of this paper are indeed related to stronger creditor protection, the direct effects of the housing collateral law should have been even stronger in areas where contract enforcement is weaker.

We test this hypothesis by comparing whether home-backed loans increase in areas with higher homeownership and weaker contract enforcement. To measure the degree of contract enforcement, we take 
information on court congestion from Justiça Aberta, a public dataset made available by the National Justice Council (CNJ) and also used in Ponticelli and Alencar (2016). ${ }^{36}$ The CNJ collects data on court productivity through monthly reports filled by each court in Brazil. These reports contain information on the location and productivity of all Brazilian courts, such as the number of pending, new, and sentenced cases, as well as the number of judges in each court. We focus on civil courts since these are responsible for judging cases involving firms.

We then measure court congestion as the log of the ratio between pending cases and the number of judges. We then interact this measure of local court congestion with our homeownership measure and present the results in Table 13. As before, we standardize both homeownership and court congestion measures. The interaction between homeownership and court congestion is positive and significant in column II, suggesting that the direct effect of bank lending is stronger in municipalities whose courts are congested. A one standard deviation increase in court congestion leads to a $3.7 \%$ further increase in home-backed lending in municipalities with one standard deviation higher homeownership (column II). This finding is consistent with housing collateral law benefiting municipalities where judicial repossession of collateral was lengthy and costly.

Court congestion might also, however, reflect other municipality-specific characteristics other than contract enforcement. We deal with this issue by comparing pairs of adjacent municipalities in column III of Table 13. Results are qualitatively and quantitatively unchanged once we compare these municipalities, which are nearby and have similar characteristics but different court congestion.

\subsubsection{Simultaneous reforms}

Next, we test whether our results on the direct effects of the housing collateral reform can be explained by other reforms and government policies enacted around the same period.

The bankruptcy reform of 2005: The housing collateral law of August 2004 was not the only creditor rights change in Brazil around the mid-2000s. In February 2005, the government also passed a bankruptcy law that only affected firms but not individuals nor individual entrepreneurs. This bankruptcy reform gave higher priority for secured claims in case of bankruptcy at the same time as limiting the maximum amount to be paid to workers, whose claims sit at the highest priority. As discussed by Ponticelli and Alencar (2016), and more recently Fonseca and Van Doornik (2019), this bankruptcy reform has led to a significant increase in firm borrowing. Ponticelli and Alencar (2016) show this result by comparing lending in municipalities with different levels of court congestion measured by the number of pending cases to the number of judges ratio.

Since both laws were passed one after another, we might be picking up the direct effect of the bankruptcy reform rather than the consolidation of the fiduciary lien. There are several reasons why we believe this is not the case. First and more intuitive, the law our paper analyzes is a collateral reform that also concerns individuals, while the bankruptcy reform only applies to firms. The second reason is that collateral under the fiduciary lien does not integrate the bankrupt firms' assets since the owner

\footnotetext{
${ }^{36}$ This same information was used by Fazio et al. (2019).
} 
of the collateral is the creditor until repayment (Van Doornik and Capelletto, 2015). Thus, changes in bankruptcy proceedings should not directly affect home-backed loans. Third, the fact that in our paper both direct and reallocation effects started to react in September 2004 shows that credit started to react just after the housing collateral law. Finally, we take data from local court congestion from the National Justice Council (CNJ) as in Ponticelli and Alencar (2016). Column I of Table 13 shows that even after controlling for it, we still have that homeownership is strongly associated with higher secured growth after the fiduciary lien reform. Thus, our results do not appear to be driven by the bankruptcy reform of 2005 .

Changes to Real Estate Lending: We argued throughout the paper that one of the main changes in this law was that it allowed agents to use the pre-existing fiduciary lien contract to non-real estate loans, i.e., home-backed loans. Nevertheless, this same law also brought other changes that could have also affected real estate lending. For instance, it also created the patrimônio de afetação (i.e., separate state) in case of off-plant real estate acquisitions. This separated the equity of the contractor from the equity of the real estate property, providing more security to the creditor. In case of bankruptcy, the contractor could not use the off-plan real estate property to pay its debts. Also, the acquirers of these properties could hire another contractor to continue the construction. Some specialists argue that this change helped to further improve creditors' protection in the case of real estate acquisitions.

To test whether there was also a simultaneous change in real estate lending after August 2004, we employ a similar empirical strategy as in section 4.1. However, in this case, one would expect that areas with lower homeownership would benefit from this law since credit conditions would have further improved as a consequence. To check whether the housing collateral law also affected real estate lending, we regress the growth in real estate lending against the homeownership measure employed in section 4.1. If our hypothesis is true, then we would expect a negative coefficient on this relationship. Columns I and II of Table 14 present this result. We do find that the coefficient is negative, but it is not statistically significant at the $10 \%$ level. Thus, we can conclude that simultaneous changes in 2004 to improve real estate lending did not appear to have an impact here.

Car Loans: The same law that brought changes to the housing collateral contract, i.e., law $10.931 / 2004$, also improved the repossession of cars given as collateral for their acquisition, a change in regulation that was analyzed by Assunção et al. (2014). A concern in our analysis is that we would be identifying the effects of changes in the enforceability of auto-loans and not the housing collateral one.

We do not believe this is the case since we show in Table 2 that home-backed loans increase in areas with higher homeownership. Nevertheless, Panels B and C of this table also show that total credit and secured credit increases in these areas, which might also be an effect of the auto loan part of the law. Part of the reason why banks might be reallocating credit to high homeownership areas might be due to the auto-loans. To address this issue, we take information on car loans growth from June 2004 to June 2007 from the Credit Registry and regress on homeownership in a differences-in-differences setting. Columns III and IV of Table 14 show that bank auto-loans do not change significantly statistically nor economically after the passage of the law across municipalities with different homeownership rates. 
Bolsa-Família Program: At the beginning of 2004, the federal government created a cash-transfer program aimed at low-income families. This program significantly increased its disbursements in mid2004, around the same time as the housing collateral reform. Thus, our results in terms of credit and real economic activity could be explained by the Bolsa-Familia program benefiting municipalities with higher homeownership. This concern is particularly valid since areas with higher homeownership are those with lower average income. In Appendix A.3, however, we show that Bolsa-Familia's disbursements increase at the same rate in areas with different homeownership. Thus, it does not seem to be the case that areas with higher homeownership are benefiting more from this program than other areas.

\subsubsection{Credit Reallocation: Intrabank Net Borrowing}

This paper has shown that the increased lending in high homeownership municipalities led to a reallocation of credit from other areas. To further confirm that this is the channel, we take balance sheet data from ESTBAN on bank branches intrabank borrowing and lending. Branches in high homeownership areas should be borrowing more from and/or lending less to other branches of the same bank. We confirm this finding in columns I, II and III of Table 15. Intrabank borrowing increases by $19.1 \%$ in branches located in municipalities with one standard deviation higher homeownership. Similarly, intrabank lending decreases by $13.8 \%$. Taken together, net borrowing (as \% of assets) increase by $4.4 \%$. This finding gives additional support to credit reallocation from low to high homeownership areas.

\subsubsection{Credit Reallocation: Placebo Test}

We have found that sensitive banks restrict credit to borrowers in low homeownership municipalities. However, there is no reason why sensitive banks would experience a restriction of their liabilities, such as deposits, from low to high municipalities. Using again data on balance sheet at the branch level from ESTBAN, we find that indeed sensitive banks do not experience a drop in deposits if compared to other banks. Column IV of Table 15 finds that a bank with a one standard deviation higher bank sensitivity experiences a decrease of $2.2 \%$ in deposits but this drop is not statistically significant.

\subsubsection{Credit Reallocation: Sample Representativeness}

In section 4.2, we have presented evidence that firms connected to more than one bank experience a drop in credit from sensitive banks. We have also shown that these firms are not able to fully compensate for this drop in credit supply by borrowing from alternative banks. However, a concern is that our results are being driven by these multi-lender firms and that it does not apply to the average firm. We alleviate these concerns by including in the regression firms that were connected to a single bank before the reform. While adding these firms prevents us from controlling for firm varying confounding factors, such as their choice for different banks, we would also like to make sure that our results are not driven by multi-lender firms only. Table 16 presents the results of adding single lender firms in the analysis. We see that firms connected to sensitive banks experience an even higher decrease in 
lending, and a similar decrease in interest rates charged. Overall, our results are robust to including single-lender in the analysis.

In addition to checking whether our results are robust to single-lender firms, we also ask whether they are robust to individuals. To answer this question, we take the universe of individuals in low homeownership municipalities that were borrowing from more than one bank in June 2004 and ask whether banks with higher bank sensitivity restrict credit to them. The empirical specification is similar to the one in equation (4) but now applied to individuals. From Table 17, we can see that results are overall robust to individuals as well since the same individual faces a decline in credit and an increase in interest rate by more sensitive banks.

\section{Conclusion}

This paper provides evidence on how banks reallocate credit as a result of a collateral reform that greatly enhanced the speed of repossession in home-backed loans, and the consequences of this reallocation to local economic performance and the distribution of labor across the economy. We use proprietary credit registry data from the Central Bank of Brazil to find that while the housing collateral law improved the loan terms in high homeownership municipalities, it might have caused banks to restrict credit to other borrowers as a result. This reallocation is particularly strong when banks are less liquid and capitalized. In addition to effects on bank lending, the reallocation also had real economic effects: it boosted employment, wages, firm creation and entry into entrepreneurship in high homeownership municipalities at the expense of lower employment, wages and entrepreneurship elsewhere. Finally, there is evidence that the credit reallocation triggers a reallocation of production factors within Brazil: workers seem to change jobs from municipalities with low homeownership, especially where credit was restricted the most and when the new job is in areas with high homeownership.

The main takeaway from this paper is that stronger creditor rights are not necessarily a Pareto improvement. When faced with a more creditor friendly environment in some regions, banks might optimally choose to reallocate credit to homeowners - since the loss given default of these borrowers has decreased - and away from non-homeowners, who were not directly affected by the law. These results are consistent with financial and regulatory constraints curbing banks from increasing their credit portfolio indefinitely, and therefore, needing to reallocate credit from some borrowers. Regulators should be aware of the possible credit reallocation as a consequence of implementing these policies.

\section{References}

Acharya, V., Bergant, K., Crosignani, M., Eisert, T., and McCann, F. J. (2019). The anatomy of the transmission of macroprudential policies. Working Paper.

Adelino, M., Schoar, A., and Severino, F. (2015). House prices, collateral, and self-employment. Journal of Financial Economics, 117(2):288-306. 
Assunção, J. J., Benmelech, E., and Silva, F. S. S. (2014). Repossession and the democratization of credit. The Review of Financial Studies, 27(9):2661-2689.

Beck, T., Demirguc-Kunt, A., and Maksimovic, V. (2005). Financial and legal constrains to growth: Does firm size matter? Journal of Finance, 60(1):137-177.

Berger, A. N. and Udell, G. F. (1995). Relationship lending and lines of credit in small firm finance. The Journal of Business, 68(3):351-381.

Bertrand, M. E., Duflo, E., and Mullainathan, S. (2004). How much should we trust differences-indifferences estimates? The Quarterly Journal of Economics, 119(1):249-275.

Bian, B. (2019). Globally consistent creditor protection, reallocation, and productivity. Working Paper.

Black, S. E. and Strahan, P. E. (2002). Entrepreneurship and bank credit availability. The Journal of Finance, 57(6):2807-2833.

Bustos, P., Garber, G., and Ponticelli, J. (2017). Capital allocation across regions, sectors and firms: evidence from a commodity boom in Brazil. Central Bank of Brazil Working Paper Series.

Calomiris, C. W., Larrain, M., Liberti, J. M., and Sturgess, J. D. (2017). How collateral laws shape lending and sectoral activity. Journal of Financial Economics, 123(1):163-188.

Campbell, J. Y., Giglio, S., and Pathak, P. (2011). Forced sales and house prices. American Economic Review, 101(5):2108-2131.

Campello, M. and Larrain, M. (2016). Enlarging the contracting space: Collateral menus, access to credit, and economic activity. Review of Financial Studies, 29(2):349-383.

Cerqueiro, G., Ongena, S., and Roszbach, K. (2016). Collateralization, bank loan rates, and monitoring. The Journal of Finance, 71(3):1295-1322.

Cetorelli, N. and Strahan, P. E. (2006). Finance as a barrier to entry: Bank competition and industry structure in local U.S. markets. The Journal of Finance, 61(1):437-461.

Chakrabordy, I., Goldstein, I., and MacKinlay, A. (2018). Housing price booms and crowding-out effects in bank lending. Review of Financial Studies, 31(7):2806-2853.

Corradin, S. and Popov, A. (2015). House prices, home equity borrowing, and entrepreneurship. Review of Financial Studies, 28(8):2399-2428.

Cortes, K. and Strahan, P. (2017). Tracing out capital flows: How financially integrated banks respond to natural disasters. Journal of Financial Economics, 125(1):182-199.

Cunat, V., Cvijanovic, D., and Yuan, K. (2018). Within-bank spillovers of real estate shocks. Review of Corporate Finance Studies, 7(2):157-193.

Donaldson, J. R., Gromb, D., and Piacentino, G. (forthcoming). The paradox of pledgeability. Journal of Financial Economics. 
Evans, D. S. and Jovanovic, B. (1989). An estimated model of entrepreneurial choice under liquidity constraints. Journal of Political Economy, 97(4):808-827.

Evans, D. S. and Leighton, L. S. (1989). Some empirical aspects of entrepreneurship. The American Economic Review, 79(3):519-535.

Fazio, D., Silva, T., and Skrastins, J. (2019). Court congestion, transmission of shocks and vertical integration. Working Paper.

Fonseca, J. and Van Doornik, B. (2019). Financial development, labor markets, and aggregate productivity: Evidence from Brazil. Working Paper.

Franks, J., Sussman, O., and Vig, V. (2017). The privatization of bankruptcy: Evidence from financial distress in the shipping industry. Working Paper.

Gilje, E., Loutskina, E., and Strahan, P. (2016). Exporting liquidity: Branch banking and financial integration. Journal of Finance, 71(3):1159-1184.

Gropp, R., Scholz, J. K., and White, M. J. (1997). Personal bankruptcy and credit supply and demand. The Quarterly Journal of Economics, 112(1):217-251.

Hannan, T. H. (1991). Foundations of the structure-conduct-performance paradigm in banking. Journal of Money, Credit and Banking, 23(1):58-84.

Hurst, E. and Lusardi, A. (2004). Liquidity constraints, household wealth, and entrepreneurship. Journal of Political Economy, 112(2):319-347.

Iacoviello, M. (2011). Housing wealth and consumption. Board of Governors of the Federal Reserve System - International Finance Discussion Papers 1027.

Jappelli, T., Pagano, M., and Bianco, M. (2005). Courts and banks: Effects of judicial enforcement on credit markets. Journal of Money, Credit and Banking, 37(2):223-244.

Kerr, W. R. and Nanda, R. (2009). Democratizing entry:banking deregulations, financing constraints, and entrepreneurship. Journal of Financial Economics, 94(1):124-149.

Khwaja, A. and Mian, A. (2008). Tracing the impact of bank liquidity shocks: Evidence from an emerging market. American Economic Review, 98(4):1413-1442.

King, R. G. and Levine, R. (1993). Finance and growth: Schumpeter might be right. The Quarterly Journal of Economics, 108(3):717-737.

Klein, M. A. (1971). A theory of the banking firm. Journal of Money, Credit and Banking, 3(2):205218.

Kulkarni, N. (2018). Creditor rights and allocative distortions. Working Paper.

La Porta, R., de Silanes, F. L., Shleifer, A., and Vishny, R. W. (1997). Legal determinants of external finance. The Journal of Finance, 52(3):1131-1150. 
La Porta, R., de Silanes, F. L., Shleifer, A., and Vishny, R. W. (1998). Law and finance. Journal of Political Economy, 106(6):1113-1155.

Levine, R. (1998). The legal environment, banks, and the long-run economic growth. Journal of Money, Credit and Banking, 30(3):596-613.

Levine, R. (1999). Law, finance, and economic growth. Journal of Financial Intermediation, 8(1-2):835.

Lilienfeld-Toal, U., Mookherjee, D., and Visaria, S. (2012). The distributive impact of reforms in credit enforcement: Evidence from Indian debt recovery tribunals. Econometrica, 80(2):497-58.

Loutskina, E. and Strahan, P. E. (2015). Financial integration, housing, and economic volatility. Journal of Financial Economics, 115(1):25-41.

Petersen, M. A. and Rajan, R. G. (1994). The benefits of lending relationships: Evidence from small business data. The Journal of Finance, 49(1):3-37.

Petersen, M. A. and Rajan, R. G. (1995). The effect of credit market competition on lending relationships. The Quarterly Journal of Economics, 110(2):407-443.

Pinheiro, A. C. (2003). Judiciário, reforma e economia: A visão dos magistrados. IPEA - Texto Para Discussão, 966.

Ponticelli, J. and Alencar, L. S. (2016). Court enforcement, bank loans and firm investment: Evidence from a bankruptcy reform in Brazil. The Quarterly Journal of Economics, 131(3):1365-413.

Schmalz, M. C., Sraer, D. A., and Thesmar, D. (2017). Housing collateral and entrepreneurship. The Journal of Finance, 72(1):99-132.

Schnabl, P. (2012). The international transmission of bank liquidity shocks: Evidence from an emerging market. Journal of Finance, 67(3):897-932.

Van Doornik, B. and Capelletto, L. R. (2015). Collateral after the Brazilian creditor rights reform. Central Bank of Brazil Working Paper Series 404.

Vig, V. (2013). Access to collateral and corporate debt structure: Evidence from a natural experiment. The Journal of Finance, 68(3):881-928.

Visaria, S. (2009). Legal reform and loan repayment: The microeconomic impact of debt recovery tribunals in India. American Economic Journal: Applied Economics, 1(3):59-81. 
Figure 1: Loans with Real Estate Collateral

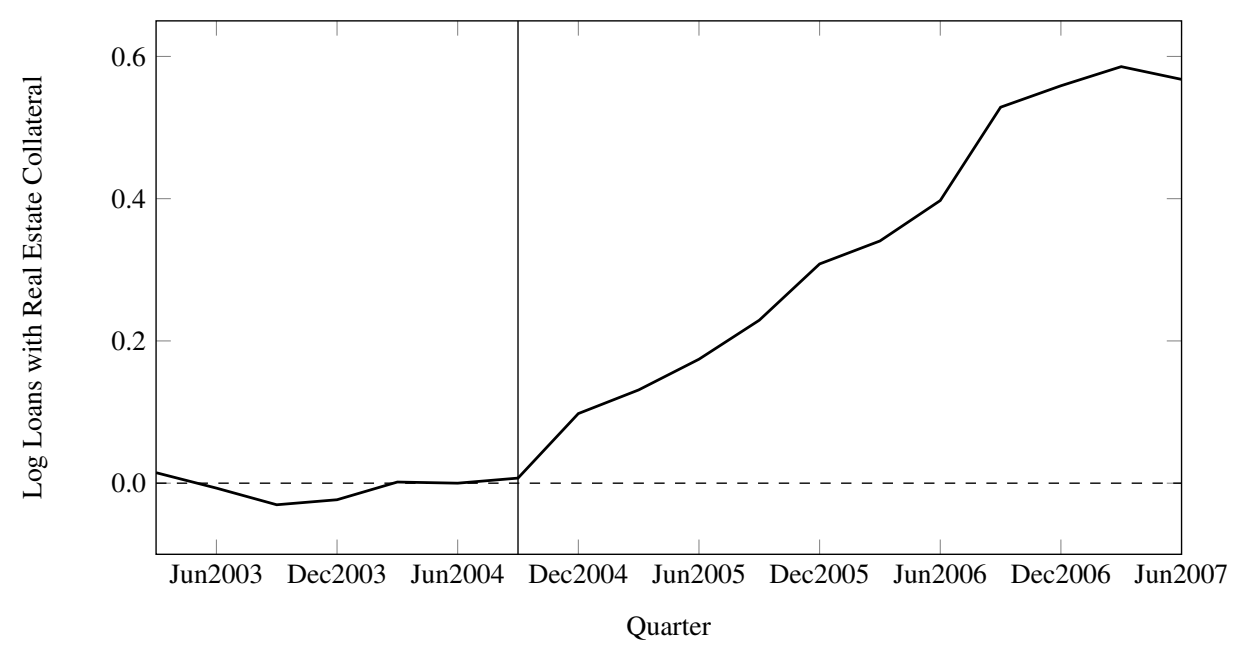

This figure plots the evolution of loans with real estate collateral for non real estate reasons in the quarters around the passage of the housing collateral law in 2004. This graph was calculated using information from the Brazilian Credit Registry (SCR), a proprietary dataset from the Central Bank of Brazil. We detrend the curve by a simple linear trend and normalize it to be zero in June 2004. The interpretation of the curve is that, for instance, in June 2007, loans with real estate collateral are about $60 \%$ above the trend if compared to June 2004. 


\section{Figure 2: Homeownership Rate Across Brazil}

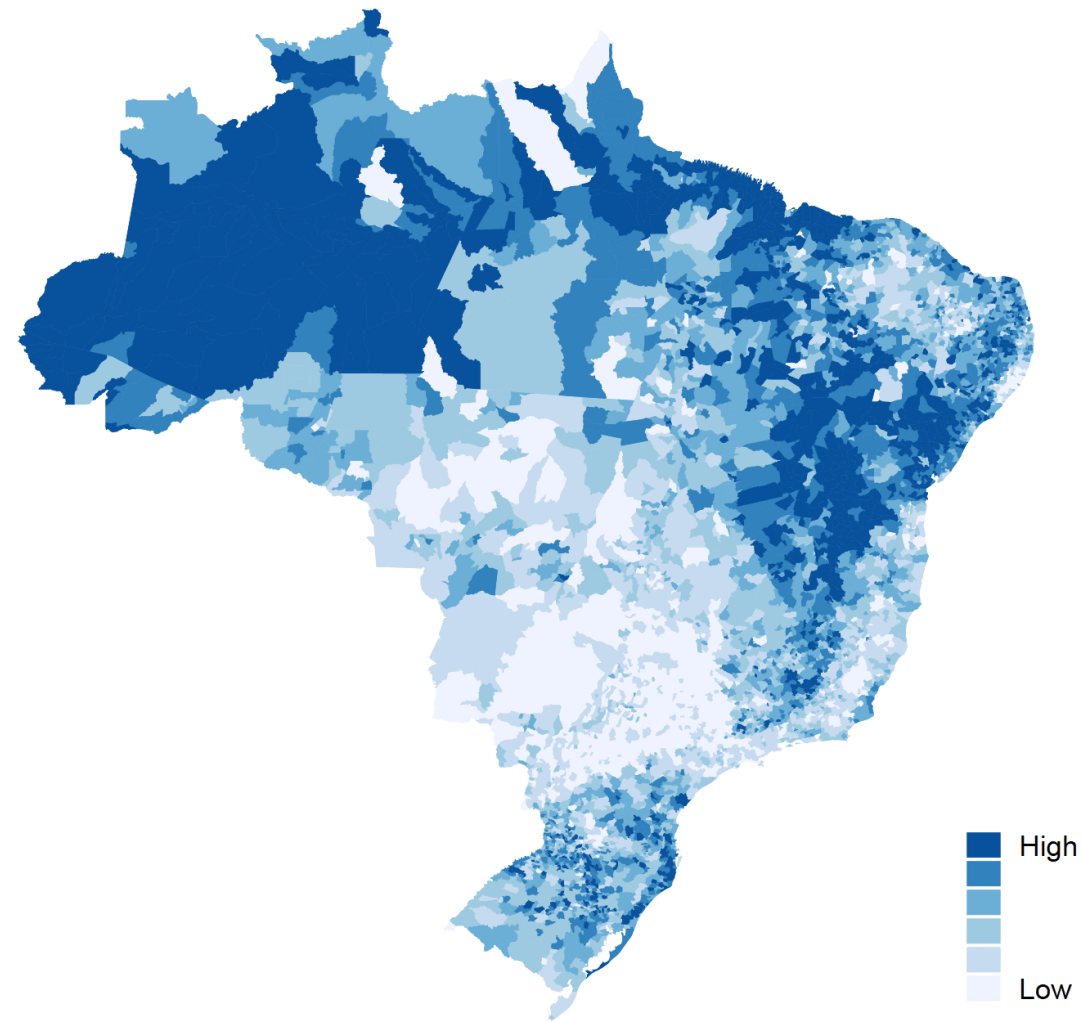

Panel A

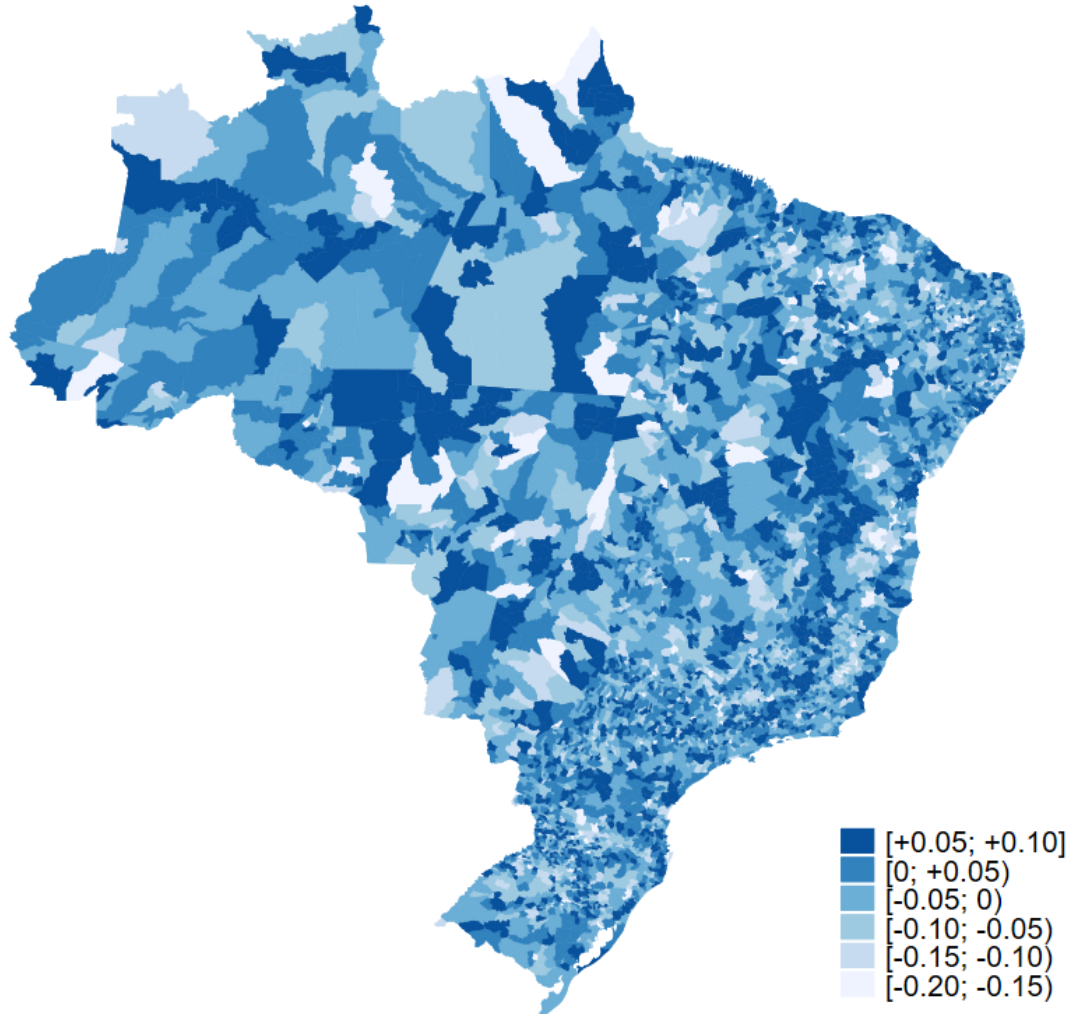

Panel B

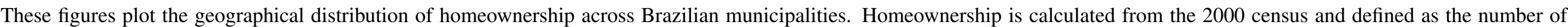

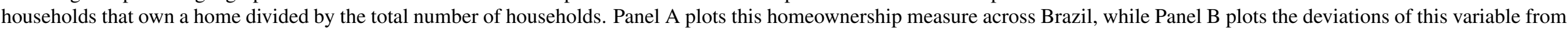
its regional average. 
Figure 3: Parallel Trends Assumption: Direct Effects

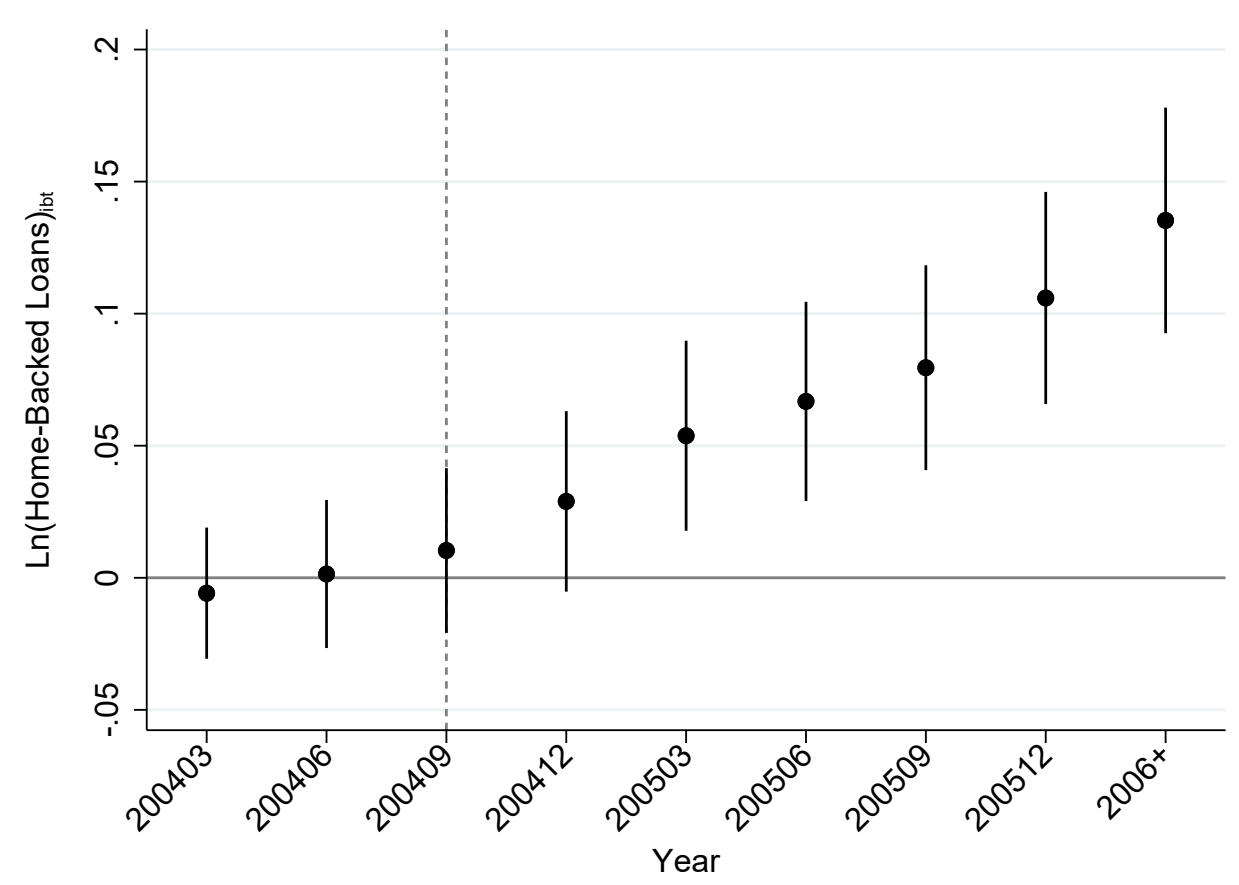

This figure plots the test of the parallel trends assumption for the direct effects of the housing collateral law, i.e., the coefficients of the regression of growth of log home-backed loans against homeownership at municipality level interacted with quarter time dummies around the passage of the law.

Figure 4: Parallel Trends Assumption: Reallocation

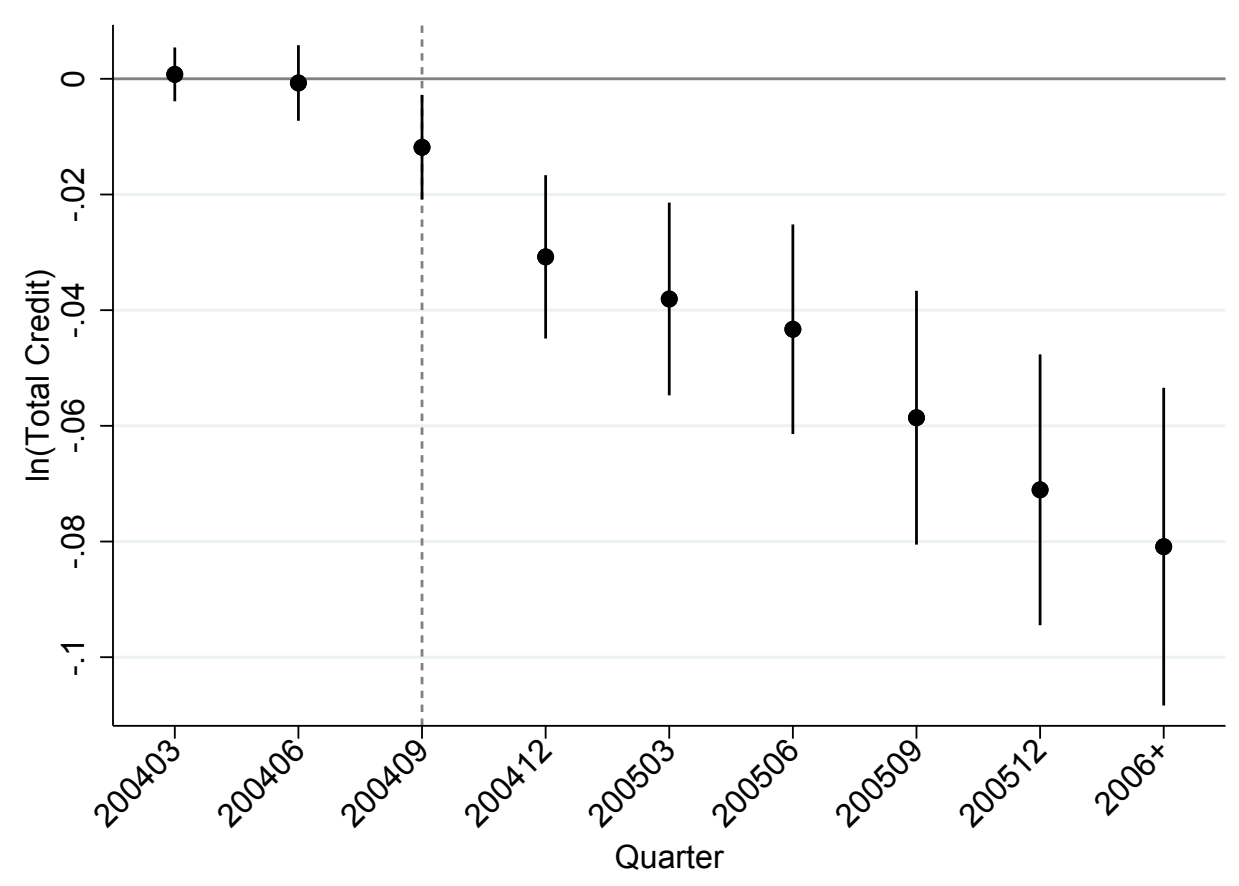

This figure plots the test of the parallel trends assumption for the indirect effects of the housing collateral law, i.e., the coefficients of the regression of growth of log credit against bank sensitivity interacted with quarter time dummies around the passage of the law. 


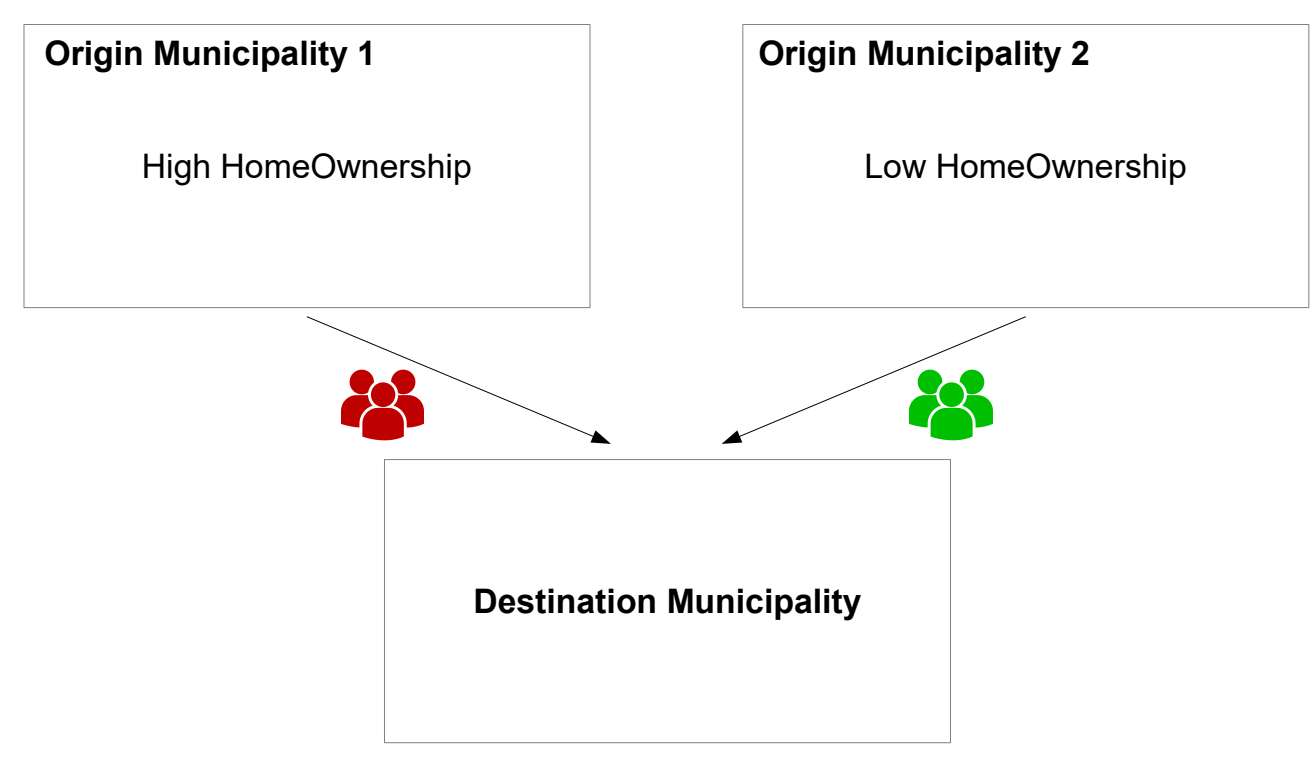

Panel A: Benchmark Specification

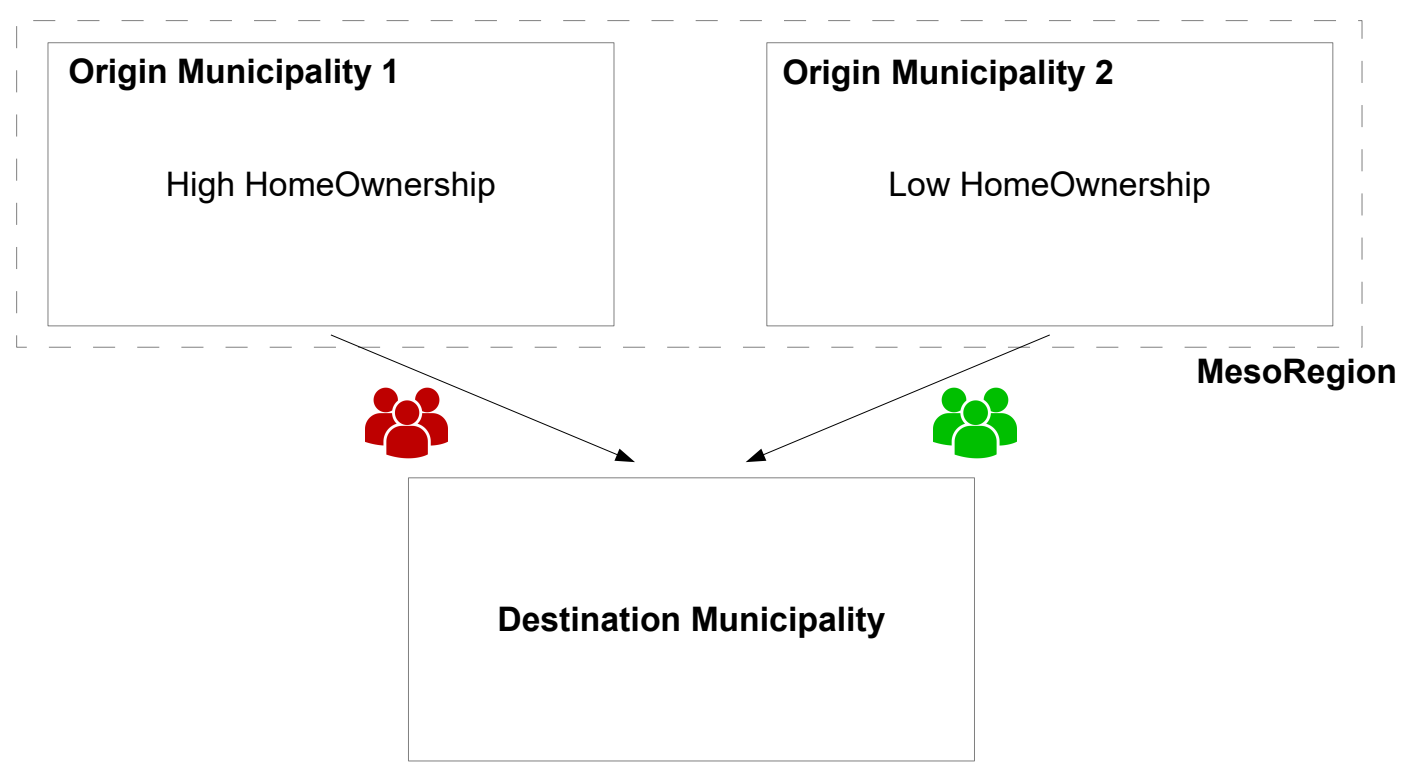

Panel B: Comparing Migration from Municipalities in the Same MesoRegion

These figures plot the empirical strategy of our Labor Migration results. We compare migration flows before and after 2004 from municipalities with different homeownership rates to the same destination municipality, as in equation (9). Panel A plots our benchmark specification, while Panel B plots an specification where we compare migration from municipalities of the same mesoregion. 
Table 1: Summary Statistics

\begin{tabular}{|c|c|c|c|c|}
\hline Variables & Level & $\mathbf{N}$ & mean & std \\
\hline \multicolumn{5}{|l|}{ Direct Effects } \\
\hline homeownership & muni & 5,505 & $72.25 \%$ & $11.87 \%$ \\
\hline $\ln (\text { home-backed loans })^{a}$ & muni-bank-year & 37,530 & 12.37 & 1.91 \\
\hline home-backed interest rate $(\%)^{a}$ & muni-bank-year & 37,530 & 20.59 & 17.71 \\
\hline home-backed loans (as \% of total credit) & muni-bank-year & 145,216 & $9.42 \%$ & $14.49 \%$ \\
\hline $\ln ($ total credit) & muni-bank-year & 145,216 & 12.92 & 1.71 \\
\hline interest rate $(\%)$ & muni-bank-year & 145,216 & 22.53 & 19.67 \\
\hline \multicolumn{5}{|l|}{ Bank Credit Spillovers ${ }^{b}$} \\
\hline bank sensitivity & bank & 88 & $7.76 \%$ & $10.37 \%$ \\
\hline $\ln ($ total credit) & muni-bank-year & 87,866 & 13.21 & 1.88 \\
\hline interest rate $(\%)$ & muni-bank-year & 87,866 & 22.93 & 19.82 \\
\hline $\ln ($ total credit $)$ & firm-bank-year & 414,460 & 10.93 & 1.77 \\
\hline interest rate $(\%)$ & firm-bank-year & 414,460 & 27.20 & 26.30 \\
\hline \multicolumn{5}{|l|}{ Real Economic Effects: Entrepreneurship } \\
\hline $\ln (\text { home-backed loans })^{a}$ & muni-year & 966 & 13.38 & 2.25 \\
\hline $\ln (\#$ of firm-owners) & muni-year & 4,952 & 2.61 & 1.83 \\
\hline $\ln (\#$ of firms $)$ & muni-year & 8,614 & 2.22 & 1.54 \\
\hline $\ln (\text { total credit })^{a}$ & muni-year & 4,818 & 12.95 & 2.56 \\
\hline \multicolumn{5}{|l|}{ Real Economic Effects: Performance } \\
\hline bank sensitivity & firm & 647,126 & $4.38 \%$ & $4.59 \%$ \\
\hline $\ln (\mathrm{empl})$ & firm-year & $1,332,490$ & 1.88 & 1.27 \\
\hline $\ln ($ wage $)$ & firm-year & $1,325,428$ & 6.34 & 0.43 \\
\hline $\ln$ (inflow) & firm-year & 419,466 & 11.96 & 2.12 \\
\hline bank sensitivity & muni & 2,753 & $8.94 \%$ & $1.79 \%$ \\
\hline $\ln (\mathrm{gdp})$ & muni-year & 11,012 & 11.10 & 1.42 \\
\hline \multicolumn{5}{|l|}{ Labor Migration } \\
\hline $\ln ($ migrants +1$)$ & orig-dest-year & $1,434,972$ & 0.51 & 0.96 \\
\hline home-backed migrants (as $\%$ of migrants) & orig-dest-year & 233,768 & $16.30 \%$ & $29.00 \%$ \\
\hline \multicolumn{5}{|l|}{ Firm Characteristics } \\
\hline age (years) & firm & $1,482,900$ & 11.57 & 9.07 \\
\hline number employees & firm & $1,486,314$ & 25.70 & 687.81 \\
\hline \multicolumn{5}{|l|}{ Bank Variables } \\
\hline capital ratio & bank & 88 & 0.22 & 0.20 \\
\hline liquid assets & bank & 88 & 0.64 & 0.23 \\
\hline $\ln$ (assets) & bank & 88 & 20.73 & 2.13 \\
\hline roa & bank & 88 & 0.01 & 0.03 \\
\hline
\end{tabular}

This table presents the summary statistics of the main variables used in this paper. We divide the variables by the section they are used in the paper. Bank credit variables were obtained from the Brazilian Credit Registry. Home-backed loans are defined as loans to individuals secured by real estate collateral and used for non-real estate purposes. Total credit aggregates all loan types (homed-backed or not) to both individuals and firms unless otherwise stated. Homeownership is the fraction of households that are owned by their residents in each municipality, calculated from the Census of 2000. Bank sensitivity measures how sensitive a bank is to the housing collateral reform. It is calculated as the share of each bank credit portfolio located in areas with high homeownership, i.e., in the upper median of homeownership, as of June/2004. We also use weighted averages of bank sensitivity at the firm, local industry, and municipality level. These averages are calculated using the share of credit in June/2004 as weights. Inflow is measured as the total amount of payments received by the firm in the Brazilian System of Payments. Empl is the number of employees of the firm, measured from the universe of labor contracts in RAIS dataset. Wage is the average wage measured as the total payroll divided by the number of employees. We calculate labor migration using the RAIS database. We first observe employees at the beginning of 2002 (pre-reform) and 2005 (post-reform) and see whether they have changed jobs to a new municipality two years after, i.e., at the beginning of 2004 and 2007, respectively. We calculate the migration flow for each origination-destination municipality pair for these years. Home-backed migrants is the number of migrants that start working in a firm whose owner has a positive home-backed loan balance. Firm characteristics, such as age and number of employees, are used in heterogeneous tests and control variables throughout the paper. Bank balance sheet variables are calculated as of December 2004. Capital ratio is defined as bank equity divided by total assets. Ln(assets) is used as a proxy of bank size. Liquid assets is the ratio between non-credit assets to total assets. ROA is the ratio between bank profit and total assets. ${ }^{a}$ : information calculated using loans to individuals only. ${ }^{b}$ : summary statistics calculated for municipalities in the lower median of homeownership only. 
Table 2: Does the Housing collateral Law of 2004 Improve Access to Credit?

\begin{tabular}{|c|c|c|c|c|c|c|c|c|c|}
\hline & \multicolumn{3}{|c|}{$\Delta \ln (\text { home-backed loans })_{m b}$} & \multicolumn{3}{|c|}{$\Delta$ int rate of home-backed loans ${ }_{m b}$} & \multicolumn{3}{|c|}{$\Delta$ home-backed loans (as $\%$ of credit) $m b$} \\
\hline & $\mathrm{I}$ & II & III & IV & $\mathrm{V}$ & VI & VII & VIII & IX \\
\hline Homeownership $_{m}$ & $\begin{array}{c}0.204 * * * \\
(0.0432)\end{array}$ & $\begin{array}{c}0.151 * * * \\
(0.0323)\end{array}$ & $\begin{array}{c}0.168 * * * \\
(0.0294)\end{array}$ & $\begin{array}{l}-0.265 * \\
(0.1448)\end{array}$ & $\begin{array}{c}-1.002 * * * \\
(0.2267)\end{array}$ & $\begin{array}{c}-0.781 * * * \\
(0.3015)\end{array}$ & $\begin{array}{c}0.009 * * \\
(0.004)\end{array}$ & $\begin{array}{c}0.011 * * * \\
(0.0014)\end{array}$ & $\begin{array}{c}0.008 * * * \\
(0.0014)\end{array}$ \\
\hline $\begin{array}{l}\text { Obs } \\
\text { Bank FE } \\
\text { Region FE } \\
\text { Bank * Inc per Capita * Region FE }\end{array}$ & $\begin{array}{c}18,561 \\
\text { Yes }\end{array}$ & $\begin{array}{l}18,561 \\
\text { Yes } \\
\text { Yes }\end{array}$ & 17,255 & $\begin{array}{c}18,561 \\
\text { Yes }\end{array}$ & $\begin{array}{l}18,561 \\
\text { Yes } \\
\text { Yes }\end{array}$ & Yes & $\begin{array}{c}72,007 \\
\text { Yes }\end{array}$ & $\begin{array}{l}72,007 \\
\text { Yes } \\
\text { Yes }\end{array}$ & 69,483 \\
\hline \multirow{2}{*}{ Bank $*$ Inc per Capita $*$ Region FE } & \multicolumn{3}{|c|}{$\Delta \ln (\text { total credit })_{m b}$} & \multicolumn{3}{|c|}{$\Delta$ int rate of total credit ${ }_{m b}$} & & & \\
\hline & $\mathrm{X}$ & XI & XII & XIII & XIV & $\mathrm{XV}$ & & & \\
\hline Homeownership $_{m}$ & $\begin{array}{c}0.087 * * * \\
(0.0201)\end{array}$ & $\begin{array}{c}0.103 * * * \\
(0.0124)\end{array}$ & $\begin{array}{c}0.064 * * * \\
(0.014)\end{array}$ & $\begin{array}{c}0.303 \\
(0.319)\end{array}$ & $\begin{array}{c}-1.069 * * * \\
(0.278)\end{array}$ & $\begin{array}{c}-0.854 * * \\
(0.332)\end{array}$ & & & \\
\hline $\begin{array}{l}\text { Obs } \\
\text { Bank FE } \\
\text { Region FE } \\
\text { Bank } * \text { Inc per Capita } * \text { Region FE }\end{array}$ & $\begin{array}{c}72,007 \\
\text { Yes }\end{array}$ & $\begin{array}{l}72,007 \\
\text { Yes } \\
\text { Yes }\end{array}$ & 69,483 & $\begin{array}{c}72,007 \\
\text { Yes }\end{array}$ & $\begin{array}{l}72,007 \\
\text { Yes } \\
\text { Yes }\end{array}$ & 69,483 & & & \\
\hline
\end{tabular}

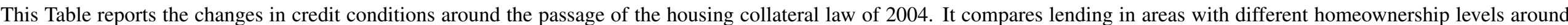

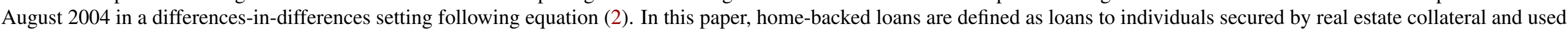

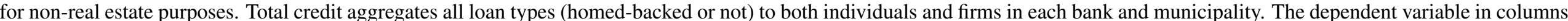

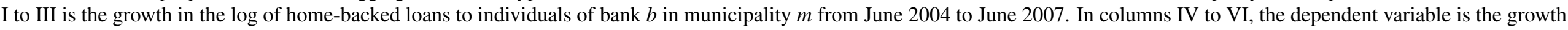

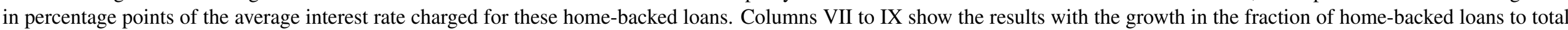

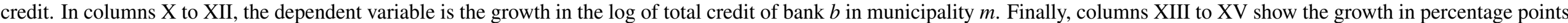

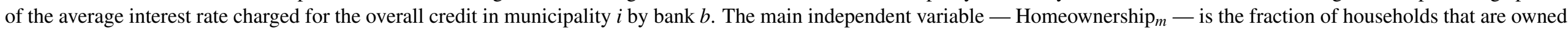

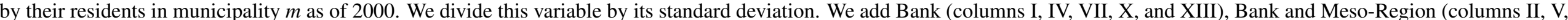

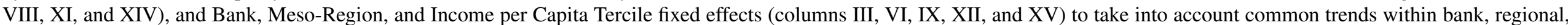

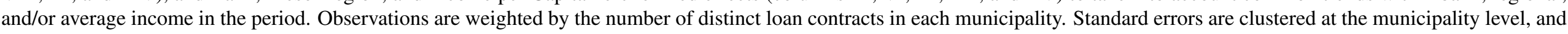
they are presented in parenthesis. *,**, and *** denote significance of $10 \%, 5 \%$, and $1 \%$, respectively. 
Table 3: Credit Spillovers: Municipality Level

\begin{tabular}{|c|c|c|c|c|}
\hline & $\Delta \ln (\text { total credit })_{m b}$ & $\Delta$ int rate $m b$ & $\Delta \ln (\text { total credit })_{m b}$ & $\Delta$ int rate $_{m b}$ \\
\hline & I & II & III & IV \\
\hline Bank Sensitivity $_{b}$ & $\begin{array}{c}-0.088 * * * \\
(0.0120)\end{array}$ & $\begin{array}{c}0.141 \\
(0.1102)\end{array}$ & $\begin{array}{c}-0.066 * * * \\
(0.0236)\end{array}$ & $\begin{array}{c}0.359 * * \\
(0.1408)\end{array}$ \\
\hline Obs & 43,932 & 43,932 & 43,788 & 43,788 \\
\hline Muni FE & Yes & Yes & Yes & Yes \\
\hline Bank Controls & & & Yes & Yes \\
\hline
\end{tabular}

This Table reports the credit spillover effects of the housing collateral law of 2004. It compares lending in low homeownership municipalities by banks with different sensitivity to the reform around 2004 in a differences-in-differences setting. Note that the results are already presented in first differences for simplicity. The dependent variable is the growth in the $\log$ of total lending in municipality $m$ and bank $b$ from June 2004 to June 2007 in odd columns and the growth in interest rates in even columns. The main independent variable Bank Sensitivity $b_{b}$ is the share of bank $b$ 's credit portfolio located in areas with high homeownership. We divide the Bank Sensitivity ${ }_{b}$ measure by its standard deviation. We add municipality fixed effects in all specifications, controlling for any change in loan demand at the municipality level around the reform. In columns III and IV, we also add bank controls, such as the log of assets, log of liquid assets, capital ratio, and a bank ownership dummy. Robust standard errors are presented in parenthesis. *, **, and *** denote significance of $10 \%, 5 \%$, and $1 \%$, respectively. 
Table 4: Credit Spillovers: Firm Level

\begin{tabular}{|c|c|c|c|c|}
\hline & $\Delta \ln (\text { total credit })_{i b}$ & $\Delta$ int rate $i b$ & $\Delta \ln (\text { total credit })_{i b}$ & $\Delta$ int rate $_{i b}$ \\
\hline & $\mathrm{I}$ & II & III & IV \\
\hline Bank Sensitivity $_{b}$ & $\begin{array}{c}-0.058 * * * \\
(0.0043)\end{array}$ & $\begin{array}{c}0.242 * \\
(0.1235)\end{array}$ & $\begin{array}{c}-0.037 * * * \\
(0.0045)\end{array}$ & $\begin{array}{c}0.468 * * * \\
(0.1603)\end{array}$ \\
\hline Obs & 173,668 & 173,668 & 173,668 & 173,668 \\
\hline Firm FE & Yes & Yes & Yes & Yes \\
\hline Bank Controls & & & Yes & Yes \\
\hline
\end{tabular}

This Table reports the credit spillover effects of the housing collateral law of 2004. It compares lending to firms in low homeownership municipalities by banks with different sensitivity to the reform around 2004 in a differences-in-differences setting. Note that the results are already presented in first differences for simplicity. The dependent variable is the growth in the log of total lending in firm $i$ and bank $b$ from June 2004 to June 2007 in odd columns and the growth in interest rates in even columns. The main independent variable Bank Sensitivity $b$ is the share of bank $b$ 's credit portfolio located in areas with high homeownership. We divide the Bank Sensitivity ${ }_{b}$ measure by its standard deviation. We add firm fixed effects in all specifications, controlling for any change in loan demand at the firm level around the reform. In columns III and IV, we also add bank controls, such as the log of assets, log of liquid assets, capital ratio, and a bank ownership dummy. Robust standard errors are presented in parenthesis. *,**, and *** denote significance of $10 \%, 5 \%$, and $1 \%$, respectively. 
Table 5: Credit Spillovers: Banks' Financial Constraints

\begin{tabular}{|c|c|c|}
\hline & $\Delta \ln (\text { total credit })_{i b}$ & $\Delta$ int rate $_{i b}$ \\
\hline & I & IV \\
\hline Bank Sensitivity $_{b}$ & $\begin{array}{c}-0.027 * * * \\
(0.0091)\end{array}$ & $\begin{array}{c}-0.153 \\
(0.1866)\end{array}$ \\
\hline Bank Sensitivity $_{b} *$ Capital Ratio $_{b}$ & $\begin{array}{c}0.024 * * * \\
(0.0085)\end{array}$ & $\begin{array}{c}-1.239 * * * \\
(0.1809)\end{array}$ \\
\hline Bank Sensitivity $_{b} *$ Liquidity Ratio $_{b}$ & $\begin{array}{c}0.027 * * * \\
(0.0054)\end{array}$ & $\begin{array}{c}-0.819 * * * \\
(0.1163)\end{array}$ \\
\hline Obs & 173,633 & 173,633 \\
\hline Firm FE & Yes & Yes \\
\hline Bank Controls & Yes & Yes \\
\hline
\end{tabular}

This Table reports how the credit spillover effects of the housing collateral law of 2004 change with banks' financial constraints. The dependent variable is the growth in the $\log$ of total lending in firm $i$ and bank $b$ from June 2004 to June 2007 in column I, and the growth in interest rates in column II. The main independent variable Bank Sensitivity $y_{b}$ is the share of bank $b$ 's credit portfolio located in areas with high homeownership. We divide the Bank Sensitivity $b$ measure by its standard deviation. We interact Bank Sensitivity $b$ with the ratio between bank $b$ 's capital and total assets $\left(\right.$ Capital Ratio $_{b}$ ), and the ratio of non-credit assets by total assets (Liquidity Ratio $b$ ). Capital Ratio $b$ and Liquidity Ratio $_{b}$ are normalized by subtracting their means and dividing the difference by their standard deviations. We add firm fixed effects in all specifications, controlling for any change in loan demand at the firm level around the reform. We also add bank controls, such as the log of assets, log of liquid assets, capital ratio, and a bank ownership dummy. Robust standard errors are presented in parenthesis. $*, * *$, and $* * *$ denote significance of $10 \%, 5 \%$, and $1 \%$, respectively. 
Table 6: Credit Spillovers: Different Aggregations of the Data

\begin{tabular}{|c|c|c|c|c|c|c|}
\hline \multirow{2}{*}{ Panel A: Firm Level } & $\Delta \ln (\text { total credit })_{i}$ & $\Delta$ int rate $_{i}$ & $\Delta \ln (\text { total credit })_{i}$ & $\Delta$ int rate ${ }_{i}$ & $\Delta \ln (\text { total credit })_{i}$ & $\Delta$ int rate ${ }_{i}$ \\
\hline & $\mathrm{I}$ & II & III & IV & $\mathrm{V}$ & VI \\
\hline Bank Sensitivity $_{i}$ & $\begin{array}{c}-0.099 * * * \\
(0.0091)\end{array}$ & $\begin{array}{l}1.298 * * * \\
(0.1568)\end{array}$ & $\begin{array}{c}-0.052 * * * \\
(0.0131)\end{array}$ & $\begin{array}{c}0.979 * * * \\
(0.2245)\end{array}$ & $\begin{array}{c}-0.062 * * * \\
(0.0161)\end{array}$ & $\begin{array}{l}1.260 * * * \\
(0.2864)\end{array}$ \\
\hline $\begin{array}{l}\text { Obs } \\
\text { Muni*Ind FE } \\
\text { Muni*Ind*Size*Age FE }\end{array}$ & 118,833 & 118,833 & $\begin{array}{c}92,264 \\
\text { Yes }\end{array}$ & $\begin{array}{c}92,264 \\
\text { Yes }\end{array}$ & $\begin{array}{c}65,555 \\
\text { Yes }\end{array}$ & $\begin{array}{c}65,555 \\
\text { Yes }\end{array}$ \\
\hline \multirow{2}{*}{ Panel B: Local Industry Level } & $\Delta \ln (\text { total credit })_{m k}$ & $\Delta$ int rate ${ }_{m k}$ & $\Delta \ln (\text { total credit })_{m k}$ & $\Delta$ int rate ${ }_{m k}$ & $\Delta \ln (\text { total credit })_{m k}$ & $\Delta$ int rate ${ }_{m k}$ \\
\hline & I & II & III & IV & $\mathrm{V}$ & VI \\
\hline Bank Sensitivity $_{m k}$ & $\begin{array}{c}-0.087 * * * \\
(0.0183)\end{array}$ & $\begin{array}{l}1.622 * * * \\
(0.4757)\end{array}$ & $\begin{array}{c}-0.088 * * * \\
(0.0176)\end{array}$ & $\begin{array}{l}1.687 * * * \\
(0.4348)\end{array}$ & $\begin{array}{c}-0.075^{* * * *} \\
(0.0168)\end{array}$ & $\begin{array}{l}1.289 * * \\
(0.3978)\end{array}$ \\
\hline $\begin{array}{l}\text { Obs } \\
\text { Industry FE } \\
\text { Region* Industry FE }\end{array}$ & 17,215 & 17,215 & $\begin{array}{c}17,214 \\
\text { Yes }\end{array}$ & $\begin{array}{c}17,214 \\
\text { Yes }\end{array}$ & $\begin{array}{c}15,848 \\
\text { Yes }\end{array}$ & $\begin{array}{c}15,848 \\
\text { Yes }\end{array}$ \\
\hline
\end{tabular}

This Table reports the credit spillover effects of the housing collateral law of 2004. We aggregate credit level outcomes at the firm level (in Panel A) and at the local industry level (in Panel B). The empirical strategy compares borrowing by different firms or local industries in low homeownership municipalities and connected to banks with different sensitivity to the reform around 2004 in a differences-in-differences setting. Note that the results are already presented in first differences for simplicity. The dependent variable is the growth in the log of total lending in firm $i$ from June 2004 to June 2007 in odd columns and the growth in interest rates in even columns. In Panel A, Bank Sensitivity ${ }_{i}$ is the weighted average of Bank Sensitivity ${ }_{b}$ for each firm $i$, as defined in equation (5). In Panel B, Bank Sensitivity $m k$ is the weighted average of Bank Sensitivity $b$ for each municipality $m$ and industry $k$, as defined by equation (7). We divide the Bank Sensitivity measures by their respective standard deviations. In Panel A, we add municipality-industry fixed effects in columns III and IV, and municipality-industry-size-age fixed effects in columns V and VI to control for any common trends in similar firms connected pre-reform to banks with different sensitivity. In Panel B, we also add industry and mesoregion-industry fixed effects to compare similar local industries. Robust standard errors are presented in parenthesis. *,**, and *** denote significance of $10 \%, 5 \%$, and $1 \%$, respectively. 
Table 7: Credit Spillovers: Heterogenous Effects

\begin{tabular}{|c|c|c|c|c|}
\hline \multirow{3}{*}{ Panel A: Firm Age } & \multicolumn{2}{|c|}{ Bank-Firm Level } & \multicolumn{2}{|c|}{ Firm Level } \\
\hline & $\Delta \ln (\text { total credit })_{i b}$ & $\Delta$ int rate ${ }_{i b}$ & $\Delta \ln (\text { total credit })_{i}$ & $\Delta$ int rate $_{i}$ \\
\hline & $\mathrm{I}$ & II & III & IV \\
\hline $\begin{array}{l}\text { Bank Sensitivity } \cdot \\
\qquad \text { Age }(<=5 \text { years })\end{array}$ & $\begin{array}{c}-0.057 * * * \\
(0.0115)\end{array}$ & $\begin{array}{l}0.615 * * \\
(0.2834)\end{array}$ & $\begin{array}{l}-0.088 * * \\
(0.0384)\end{array}$ & $\begin{array}{l}2.831 * * * \\
(0.6677)\end{array}$ \\
\hline $\begin{array}{l}\text { Bank Sensitivity } \\
\qquad \text { Age }(>5 \text { years } \&<=20 \text { years })\end{array}$ & $\begin{array}{l}-0.035^{* * * *} \\
(0.008)\end{array}$ & $\begin{array}{c}0.571 * * * \\
(0.1872)\end{array}$ & $\begin{array}{l}-0.058 * * * \\
(0.0196)\end{array}$ & $\begin{array}{l}0.860 * * \\
(0.3554)\end{array}$ \\
\hline $\begin{array}{l}\text { Bank Sensitivity } \\
\qquad \text { Age }(>20 \text { years })\end{array}$ & $\begin{array}{c}-0.026^{* *} \\
(0.0113)\end{array}$ & $\begin{array}{c}0.135 \\
(0.2411)\end{array}$ & $\begin{array}{c}-0.051 \\
(0.0425)\end{array}$ & $\begin{array}{c}1.168 * \\
(0.7079)\end{array}$ \\
\hline $\begin{array}{l}\text { Obs } \\
\text { Firm FE } \\
\text { Bank Controls } \\
\text { Muni * Industry * Size * Age FE }\end{array}$ & $\begin{array}{c}173,633 \\
\text { Yes } \\
\text { Yes }\end{array}$ & $\begin{array}{c}173,633 \\
\text { Yes } \\
\text { Yes }\end{array}$ & 65,555 & 65,555 \\
\hline \multirow{3}{*}{ Panel B: Firm Size } & \multicolumn{2}{|c|}{ Bank-Firm Level } & \multicolumn{2}{|c|}{ Firm Level } \\
\hline & $\Delta \ln (\text { total credit })_{i b}$ & $\Delta$ int rate ${ }_{i b}$ & $\Delta \ln (\text { total credit })_{i}$ & $\Delta$ int rate $_{i}$ \\
\hline & $\mathrm{I}$ & II & III & IV \\
\hline Bank Sensitivity $\cdot$ Small $(\leq 100 \mathrm{empl})$ & $\begin{array}{c}-0.045^{* * *} \\
(0.0075)\end{array}$ & $\begin{array}{l}0.622 * * * \\
(0.1709)\end{array}$ & $\begin{array}{c}-0.059 * * * \\
(0.0158)\end{array}$ & $\begin{array}{l}1.535^{* * *} * \\
(0.2875)\end{array}$ \\
\hline Bank Sensitivity $\cdot$ Large $(>100 \mathrm{empl})$ & $\begin{array}{c}0.005 \\
(0.0139)\end{array}$ & $\begin{array}{l}-0.316 \\
(0.2724)\end{array}$ & $\begin{array}{c}0.069 \\
(0.0758)\end{array}$ & $\begin{array}{l}-1.517 \\
(0.9422)\end{array}$ \\
\hline $\begin{array}{l}\text { Obs } \\
\text { Firm FE } \\
\text { Bank Controls } \\
\text { Muni * Industry * Size * Age FE }\end{array}$ & $\begin{array}{c}173,633 \\
\text { Yes } \\
\text { Yes }\end{array}$ & $\begin{array}{c}173,633 \\
\text { Yes } \\
\text { Yes }\end{array}$ & 65,555 & 65,555 \\
\hline
\end{tabular}

This table reports the heterogeneous effects of bank credit spillovers depending on borrowers' characteristics. We only keep firms located in municipalities in the lower median of the fraction of homeowners. The main independent variable in columns I and II is Bank Sensitivity ${ }_{b}$ : the share of bank $b$ 's credit portfolio located in areas with high homeownership. In columns III and IV, we employ Bank Sensitivity at the firm $i$ level. We interact these variables with firm age (Panel A) and firm size (Panel B) dummies. The dependent variables are total lending in odd columns and the average interest rate charged in even columns. Independent variables are normalized by their standard deviation. We add firm fixed effects and bank controls in columns I and II. In columns III and IV, we add municipality-industry-size-age fixed effects. Robust standard errors are presented in parenthesis. $*, * *$, and $* * *$ denote significance of $10 \%, 5 \%$ and $1 \%$, respectively. 
Table 8: Real Effects: Entrepreneurship

\begin{tabular}{|c|c|c|c|c|c|c|}
\hline & $\Delta \ln (\text { home-backed })_{m}$ & $\Delta \ln (\# \text { owners })_{m}$ & $\Delta \ln (\# \text { firms })_{m}$ & $\Delta \ln (\text { total credit })_{m}$ & $\Delta \ln (\# \text { owners })_{m}$ & $\Delta \ln (\text { \# firms })_{m}$ \\
\hline & $\mathrm{I}$ & II & III & IV & $\mathrm{V}$ & VI \\
\hline Homeownership $_{m}$ & $\begin{array}{c}0.486^{*} \\
(0.2859)\end{array}$ & $\begin{array}{c}0.164 * * * \\
(0.0429)\end{array}$ & $\begin{array}{c}0.135^{* * *} \\
(0.0153)\end{array}$ & & & \\
\hline Bank Sensitivity $_{m}$ & & & & $\begin{array}{c}-0.496 * * * \\
(0.0982)\end{array}$ & $\begin{array}{c}-0.188^{* * * *} \\
(0.0519)\end{array}$ & $\begin{array}{l}-0.030^{*} \\
(0.0161)\end{array}$ \\
\hline Obs & 457 & 2,459 & 4,261 & 1,620 & 1,651 & 2,387 \\
\hline Region FE & Yes & Yes & Yes & Yes & Yes & Yes \\
\hline
\end{tabular}

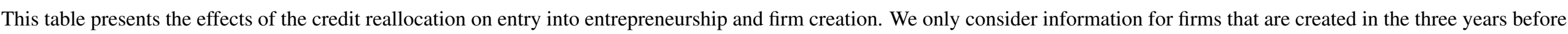

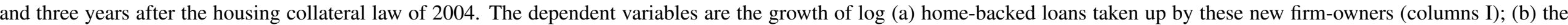

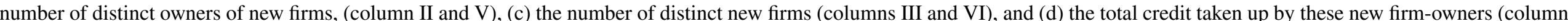

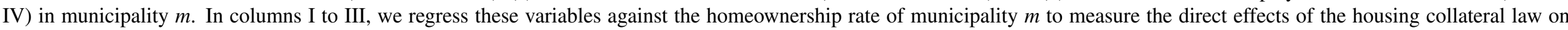

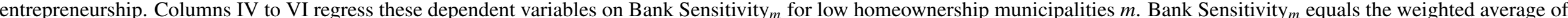

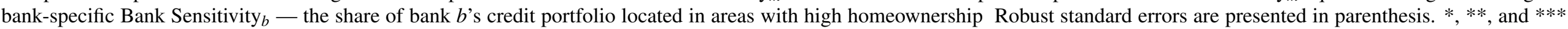
denote significance of $10 \%, 5 \%$, and $1 \%$, respectively. 
Table 9: Real Effects: Firm Performance

\begin{tabular}{|c|c|c|c|c|c|c|c|c|}
\hline & $\Delta \ln (\text { cash in })_{i}$ & $\Delta \ln (\mathrm{empl})_{i}$ & $\Delta \ln (\text { wage })_{i}$ & ${\overline{\Delta \ln (\text { wage })_{i}}}_{i}$ & $\Delta \ln (\text { cash in })_{i}$ & $\Delta \ln (\mathrm{empl})_{i}$ & $\Delta \ln (\text { wage })_{i}$ & $\overline{\Delta \ln (\text { wage })_{i}}$ \\
\hline & $\mathrm{I}$ & II & III & IV & $\mathrm{V}$ & VI & VII & VIII \\
\hline Homeownership $_{m}$ & $\begin{array}{l}0.012 * * * \\
(0.004)\end{array}$ & $\begin{array}{l}0.008 * * * \\
(0.0008)\end{array}$ & $\begin{array}{l}0.013 * * * \\
(0.0003)\end{array}$ & $\begin{array}{l}0.007 * * * \\
(0.0003)\end{array}$ & & & & \\
\hline Bank Sensitivity $_{i}$ & & & & & $\begin{array}{c}-0.018^{* * *} \\
(0.0065)\end{array}$ & $\begin{array}{c}-0.023^{* * *} \\
(0.0011)\end{array}$ & $\begin{array}{l}-0.004 * * * \\
(0.0004)\end{array}$ & $\begin{array}{l}-0.001 * * \\
(0.0004)\end{array}$ \\
\hline Obs & 171,815 & 686,028 & 682,271 & 601,303 & 97,904 & 460,465 & 457,737 & 395,652 \\
\hline $\begin{array}{l}\text { Ind } * \text { Size } * \text { Age FE } \\
\text { Muni } * \text { Ind } * \text { Size } * \text { Age FE }\end{array}$ & Yes & Yes & Yes & Yes & Yes & Yes & Yes & Yes \\
\hline
\end{tabular}

This table presents the results of the effects of the credit reallocation on firm performance. The dependent variables are the growth of $\log$ (a) cash inflow, measured as the total amount of payments received by the firm in the Brazilian System of Payments (columns I and IV); (b) the number of employees, measured from the universe of labor contracts in RAIS dataset (column II and V), (c) the average wage measured as total payroll divided by the number of employees (columns III and VI). We aggregate these variables at the firm-level for the years of 2003 and 2007. In columns I to III, we regress these variables against homeownership at the municipality $m$ level to measure the direct effects of the housing collateral law. Columns IV to VI regress these dependent variables on Bank Sensitivity $i$ for a firm $i$ in low homeownership municipalities. The main independent variable Bank Sensitivity ${ }_{i}$ is the weighted average of Bank Sensitivity ${ }_{b}$ for each firm $i$. We weight Bank Sensitivity $_{b}$ using the outstanding credit each firm $i$ has with bank $b$ in June 2004, before the reform. Bank Sensitivity ${ }_{b}$ is the share of bank $b$ 's credit portfolio located in areas with high homeownership in June 2004, as well. We add industry-size fixed effects in columns I to III and municipality-industry-size fixed effects in column IV to VI. Robust standard errors are presented in parenthesis. $*, * *$, and $* * *$ denote significance of $10 \%, 5 \%$, and $1 \%$, respectively. 
Table 10: Local Economic Performance

\begin{tabular}{lcc}
\hline \hline & \multicolumn{2}{c}{$\Delta \ln (\mathrm{gdp})_{m}$} \\
\cline { 2 - 3 } & $\mathrm{I}$ & $\mathrm{II}$ \\
\hline \hline Homeownership $_{m}$ & $0.011^{* *}$ & \\
& $(0.0049)$ & \\
Bank Sensitivity $m$ & & $-0.020^{* * *}$ \\
& & $(0.0072)$ \\
\hline Obs & & 2,752 \\
Region FE & 5,506 & Yes \\
\hline \hline
\end{tabular}

This table presents results on the effects of the home-equity law on local economic performance. In column I, we regress the growth of the log of GDP and the growth of log local tax revenue on Homeownership. In column II, we regress the same variable on Bank Sensitivity ${ }_{m}$, a weighted average of bank sensitivity. Standard errors are clustered at the municipality level, and they are presented in parenthesis. *, **, and $* * *$ denote significance of $10 \%, 5 \%$, and $1 \%$, respectively. 
Table 11: Real Reallocation: Labor Migration

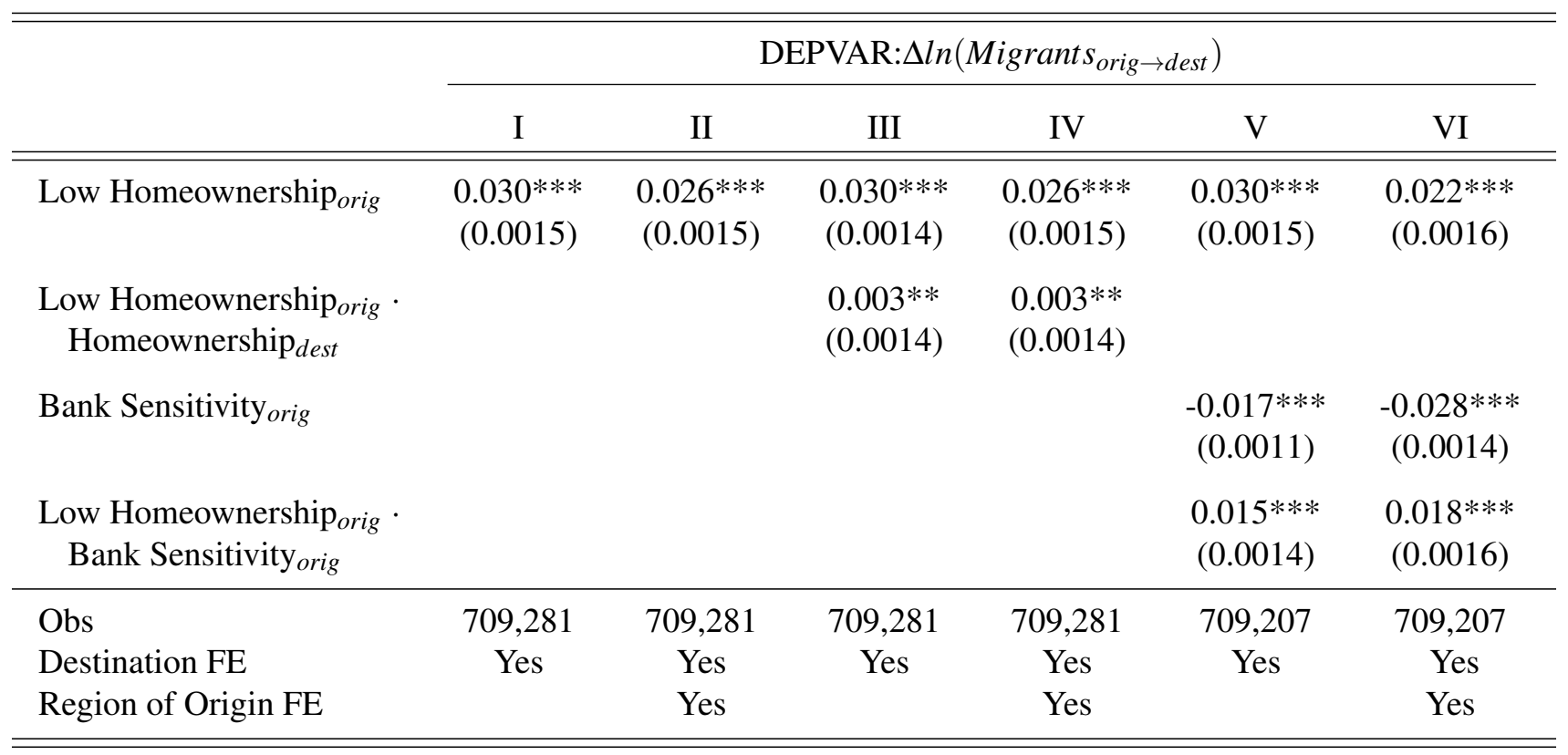

This table presents evidence on cross-municipality migration as a result of the credit reallocation. The data comes from the universe of labor contracts from RAIS 2002-2007. With this data, we can follow the employees' job history and calculate how many changed their jobs to a new municipality. We first observe employees at the beginning of 2002 (pre-reform) and 2005 (post-reform) and see whether they have changed jobs to a new municipality two years after, i.e., at the beginning of 2004 and 2007, respectively. We calculate the migration flow for each origination-destination municipality pair for these years. The dependent variable is the change in the log of migration within each origination-destination pair. In columns I and II, we are interested in determining whether net migration increases in municipalities in the lower median

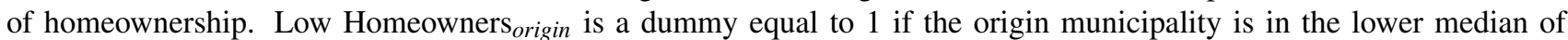
homeownership. In columns III and IV, we are interested in determining whether this net migration flow is more relevant when the destination has a higher homeownership level. Homeownership dest $_{\text {is }}$ the fraction of households that are owned by their residents in municipality dest as of 2000. In columns V and VI, we ask whether the migration flow is stronger when bank sensitivity at the origin municipality is higher. Bank Sensitivity ${ }_{i}$ equals the weighted average of bank-specific Bank Sensitivity $b_{b}$ - bank's b fraction of credit to borrowers in areas in the upper median of homeownership. Robust standard errors are presented in parenthesis. $* * *$, and $* * *$ denote significance of $10 \%, 5 \%$, and $1 \%$, respectively. 
Table 12: Real Reallocation: Labor Migration to Firms that Benefit from the Housing Collateral Law

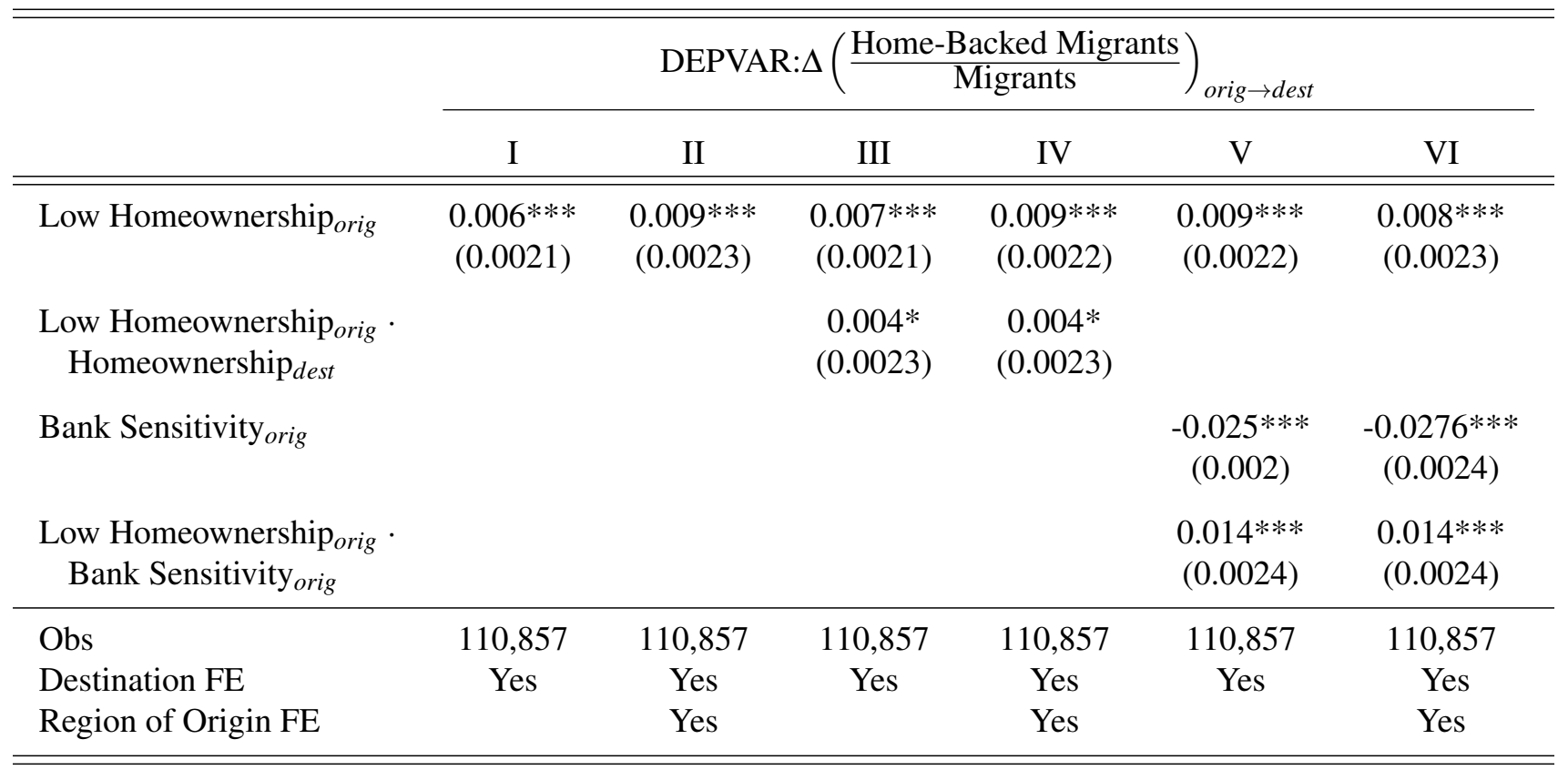

This table presents evidence on cross-municipality migration as a result of the credit reallocation. The data comes from the universe of labor contracts from RAIS 2002-2007. With this data, we can follow the employees' job history and calculate how many changed their jobs to a new municipality. We first observe employees at the beginning of 2002 (pre-reform) and 2005 (post-reform) and see whether they have changed jobs to a new municipality two years after, i.e., at the beginning of 2004 and 2007, respectively. The dependent variable is the ratio between the migration flow to firms whose owners have a positive home-backed loans outstanding balance and the total migration flow in each origination-destination municipality pair for these years. In columns I and II, we are interested in determining whether net migration increases in municipalities

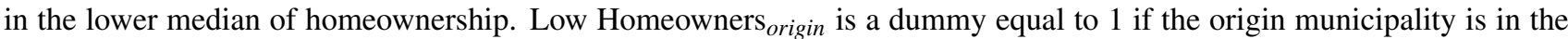
lower median of homeownership. In columns III and IV, we are interested in determining whether this net migration flow

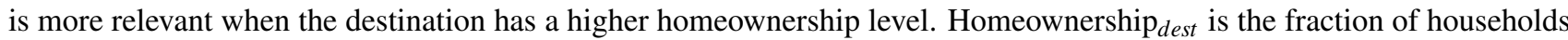
that are owned by their residents in municipality dest as of 2000. In columns V and VI, we ask whether the migration flow is stronger when bank sensitivity at the origin municipality is higher. Bank Sensitivity ${ }_{i}$ equals the weighted average of bank-specific Bank Sensitivity $b$ — bank's b fraction of credit to borrowers in areas in the upper median of homeownership. Robust standard errors are presented in parenthesis. *, **, and *** denote significance of $10 \%, 5 \%$, and $1 \%$, respectively. 
Table 13: Robustness: Court Congestion

\begin{tabular}{|c|c|c|c|}
\hline & \multicolumn{3}{|c|}{$\Delta \ln (\text { Home-Backed Loans })_{m b}$} \\
\hline & $\mathrm{I}$ & II & III \\
\hline Homeownership $_{m}$ & $\begin{array}{c}0.143 * * * \\
(0.0318)\end{array}$ & $\begin{array}{c}0.108 * * * \\
(0.0310)\end{array}$ & $\begin{array}{c}0.166^{* * * *} \\
(0.0139)\end{array}$ \\
\hline Court Congestion $_{m}$ & $\begin{array}{c}0.038 * \\
(0.0195)\end{array}$ & $\begin{array}{c}0.055^{* * * *} \\
(0.0200)\end{array}$ & $\begin{array}{c}0.024 * \\
(0.0139)\end{array}$ \\
\hline Homeownership $_{m} \cdot$ Court Congestion $_{m}$ & & $\begin{array}{c}0.037 * * * \\
(0.0152)\end{array}$ & $\begin{array}{c}0.021^{*} \\
(0.0127)\end{array}$ \\
\hline Obs & 18,287 & 18,287 & 94,213 \\
\hline Bank FE & Yes & Yes & Yes \\
\hline Region FE & Yes & Yes & \\
\hline Pair Adjacent Muni FE & & & Yes \\
\hline
\end{tabular}

This Table presents robustness tests on the direct effects of the passage of the 2004 real estate collateral reform. We assess whether the credit increase in high homeownership municipalities is more pronounced if these municipalities have more congested courts, as well. The dependent variable is the growth in the log of home-backed loans of bank $b$ in municipality $m$ from June 2004 to June 2007. Homeownership $m$ is the fraction of households that are owned by their residents in municipality $m$ as of 2000. Court Congestion $m$ is defined as the $\log$ of the ratio between pending cases in local civil courts divided by the number of judges working in them. We standardize both Homeownership and Court Congestion by subtracting their averages and dividing these differences by their respective standard deviations. We add bank and mesoregion fixed effects in columns I and II, and bank and pair of adjacent municipalities in column III. Robust standard errors are presented in parenthesis. $* * *$, and $* * *$ denote significance of $10 \%, 5 \%$, and $1 \%$, respectively. 
Table 14: Robustness: Confounding Reforms

\begin{tabular}{lcccccc}
\hline \hline \multirow{2}{*}{} & \multicolumn{2}{c}{$\Delta \ln (\text { real estate credit })_{m b}$} & & \multicolumn{2}{c}{$\Delta \ln$ (auto-loans $)_{m b}$} \\
\cline { 2 - 3 } \cline { 5 - 6 } & I & II & & III & IV \\
\hline \hline Homeownership ${ }_{m}$ & 0.062 & -0.038 & & 0.012 & 0.044 \\
& $(0.0569)$ & $(0.033)$ & & $(0.0571)$ & $(0.0344)$ \\
\hline Obs & 9,455 & 9,455 & & 21,433 & 21,433 \\
Region FE & Yes & Yes & & Yes & Yes \\
Bank FE & Yes & Yes & & Yes & Yes \\
\hline \hline
\end{tabular}

This table presents some robustness tests of the direct and indirect effects of the 2004 real estate collateral reform. In columns I and II, we deal with the concern that the 2004 reform had an impact on real estate lending. In column I, the dependent variable is the growth of the log of housing employment in municipality $m$, and in column II, it is real estate lending of bank $b$ in municipality $m$. In columns III to V, we test if branches in municipalities with high homeownership increase their intra-bank borrowing. The dependent variable in column III is the growth in intrabank lending; in column IV is the growth in intrabank borrowing, and in column $\mathrm{V}$ it is the growth of net interbank borrowing divided by total assets. Homeownership $m$ is the fraction of households that are owned by their residents in municipality $m$ as of 2000. We divide this variable by its standard deviation. We add meso-region fixed effects in all specifications. In columns II to V, we also add bank fixed effects. Robust standard errors are presented in parenthesis. *,**, and $* * *$ denote significance of $10 \%, 5 \%$, and $1 \%$, respectively. 
Table 15: Robustness: Intrabank Lending and Borrowing

\begin{tabular}{|c|c|c|c|c|}
\hline & $\Delta \ln$ (intrabank lending $)_{m b}$ & $\Delta \ln (\text { intrabank borrow })_{m b}$ & $\begin{array}{c}\Delta \text { net intrabank borrow } \\
\text { (\% Assets) }\end{array}$ & $\Delta \ln (\text { deposits })_{m b}$ \\
\hline & I & II & III & IV \\
\hline Homeownership $_{m}$ & $\begin{array}{c}-0.138 * * * \\
(0.0379)\end{array}$ & $\begin{array}{c}0.191 * * \\
(0.097)\end{array}$ & $\begin{array}{c}0.044 * * * \\
(0.0062)\end{array}$ & \\
\hline Bank Sensitivity $_{m b}$ & & & & $\begin{array}{l}-0.022 \\
(0.021)\end{array}$ \\
\hline Obs & 7,136 & 2,814 & 8,803 & 5,887 \\
\hline Region FE & Yes & Yes & Yes & \\
\hline Bank FE & Yes & Yes & Yes & \\
\hline Muni FE & & & & Yes \\
\hline
\end{tabular}

This table presents further evidence on the credit reallocation after the 2004 housing collateral law. We take data on branchlevel balance sheet from ESTBAN, a publicly available by the Central Bank of Brazil. In columns I to III, our dependent variables are the growth in the log of intrabank lending, intrabank borrowing, and the growth in the fraction of net intrabank borrowing as $\%$ of total assets, respectively. We regress these outcome variables on homeownership at the municipality level. In column IV, the dependent variable is the growth in log deposits of bank $b$ and municipality $m$. We regress this variable against Bank Sensitivity ${ }_{b}$, i.e., the share of bank $b$ 's credit portfolio located in areas with high homeownership in June 2004. Robust standard errors are presented in parenthesis. *,**, and *** denote significance of $10 \%, 5 \%$, and $1 \%$, respectively. 
Table 16: Credit Spillovers - Including Single Lender Firms

\begin{tabular}{|c|c|c|c|c|c|c|}
\hline & $\Delta \ln (\text { total credit })_{i}$ & $\Delta$ int rate $_{i}$ & $\Delta \ln (\text { total credit })_{i}$ & $\Delta$ int rate $i$ & $\Delta \ln (\text { total credit })_{i}$ & $\Delta$ int rate $_{i}$ \\
\hline & I & II & III & IV & V & VI \\
\hline Bank Sensitivity $_{i}$ & $\begin{array}{c}-0.179 * * * \\
(0.006)\end{array}$ & $\begin{array}{l}0.698 * * * \\
(0.1439)\end{array}$ & $\begin{array}{c}-0.131 * * * \\
(0.0077)\end{array}$ & $\begin{array}{l}0.724 * * * \\
(0.1941)\end{array}$ & $\begin{array}{c}-0.150 * * * \\
(0.0093)\end{array}$ & $\begin{array}{l}0.488 * * \\
(0.2313)\end{array}$ \\
\hline $\begin{array}{l}\text { Obs } \\
\text { Muni*Ind FE }\end{array}$ & 254,546 & 254,546 & $\begin{array}{c}214,092 \\
\text { Yes }\end{array}$ & $\begin{array}{c}214,092 \\
\text { Yes }\end{array}$ & 166,597 & 166,597 \\
\hline Muni*Ind*Size*Age FE & & & & & Yes & Yes \\
\hline
\end{tabular}

This Table presents results on whether banks reallocate credit from areas with low homeownership after the passage of the housing collateral law in 2004. We only keep observations of municipalities in the lower median of the fraction of homeowners. The main independent variable Bank Sensitivity ${ }_{i}$ is the weighted average of Bank Sensitivity for each firm $i$. We weight Bank Sensitivity ${ }_{b}$ using the outstanding credit each firm $i$ has with bank $b$ in June 2004, before the reform. Bank Sensitivity $b$ is the share of bank $b$ 's credit portfolio located in areas with high homeownership in June 2004, as well. The dependent variables are total lending to firm $i$ in column I, III, and $\mathrm{V}$, and the average interest rate charged to a firm $i$ in column II, IV, and VI. We divide Bank Sensitivity ${ }_{i}$ by its standard deviation. We add municipality-industry fixed effects in columns III and IV and municipality-industry-size in columns V and VI, which allow us to compare firms in the same local industry and size. Robust standard errors are presented in parenthesis. $* * *$, and $* * *$ denote significance of $10 \%, 5 \%$, and $1 \%$, respectively. 
Table 17: Credit Spillovers - Individuals

\begin{tabular}{lccc}
\hline \hline & \multicolumn{1}{c}{$\Delta \ln (\text { total credit })_{i}$} & & $\Delta$ int rate $_{i}$ \\
\cline { 2 - 2 } & $\mathrm{I}$ & $\mathrm{II}$ \\
\hline \hline Bank Sensitivity $_{b}$ & $-0.071^{* * * *}$ & & $0.319^{* * * *}$ \\
& $(0.0029)$ & & $(0.0839)$ \\
\hline Obs & 460,188 & & 460,188 \\
Individual FE & Yes & & Yes \\
\hline \hline
\end{tabular}

This Table presents results on whether banks reallocate credit from areas with low homeownership after the passage of the housing collateral law in 2004. We only keep observations of municipalities in the lower median of the fraction of homeowners. The main independent variable Bank Sensitivity ${ }_{b}$ is the share of bank $b$ 's credit portfolio located in areas with high homeownership in June 2004, as well. The dependent variables are: total lending to individual $i$ in column I and the average interest rate charged to individual $i$ in column II. We divide the Bank Sensitivity ${ }_{b}$ measure by its standard deviation. We add individual fixed effects in all specifications. Robust standard errors are presented in parenthesis. *,**, and $* * *$ denote significance of $10 \%, 5 \%$, and $1 \%$, respectively. 


\section{A Appendix}

\section{A.1 Fiduciary Lien Creation in 1997 and Real Estate Lending}

As explained in Section 2, the fiduciary lien of real estate assets was initially created by law 9,514 in November 1997. This law created the Real Estate Financial System (Sistema de Financiamento Imobiliário), whose main goal was to boost real estate lending and homeownership to counter the huge residential deficit in Brazil at the time. ${ }^{37}$ This section has two main goals. The first is to provide further evidence that the fiduciary lien contract indeed leads to better loan terms but now analyzing its effects on real estate lending. ${ }^{38}$ The second goal is to show that the early version of fiduciary lien was not fully consolidated until 2004 since his initial scope was limited to real estate lending. ${ }^{39}$

Table A1: The Fiduciary Lien for Real Estate Loans After the 1997 Law

\begin{tabular}{|c|c|c|c|c|}
\hline & $\ln (\text { total credit })_{m t}$ & $\ln (\text { free-purp loan })_{m t}$ & $\ln (\text { purp loans })_{m t}$ & $\ln (\text { owned hholds })_{m t}$ \\
\hline & $\mathrm{I}$ & II & III & IV \\
\hline Household Deficit ${ }_{m} \cdot$ Post $_{t}$ & $\begin{array}{c}0.062 * * * \\
(0.0057)\end{array}$ & $\begin{array}{c}-0.000 \\
(0.0000)\end{array}$ & $\begin{array}{c}0.128 * * * \\
(0.0104)\end{array}$ & $\begin{array}{c}0.028 * * * \\
(0.0028)\end{array}$ \\
\hline Obs & 27,683 & 27,658 & 26,309 & 5,978 \\
\hline Muni FE & Yes & Yes & Yes & Yes \\
\hline Region * Year FE & Yes & Yes & Yes & Yes \\
\hline
\end{tabular}

This table presents the analysis of law 9,514/1997 that created the real estate fiduciary lien. In the first three columns, we take data on banks' balance sheets per Brazilian municipality from ESTBAN as of December in the period between 1994 and 2002. Our dependent variables are total credit (column I); free purpose loans, such as personal loans (column II), purpose loans, such as real estate lending (column 3) by bank $b$ at municipality $m$ and year $t$. In column IV, we take data from the Brazilian censuses of 1991 and 2000 on the number of owned households in each municipality $m$. We regress all variables on Household Deficit, defined as the ratio between the number of households who are rented divided by the total number of households of the municipality in 1991. Post $t_{t}$ is a dummy equal to 1 in the years from 1997 to 2002 and 0 otherwise. Standard errors are clustered by bank-municipality. Robust standard errors are presented in parenthesis. *,**, and $* * *$ denote significance of $10 \%, 5 \%$, and $1 \%$, respectively.

Since the Brazilian Credit Registry starts recording data at the beginning of 2003, we cannot use this proprietary data to analyze the effects of the 1997 law. We then take publicly balance sheet information on Brazilian branches from ESTBAN to perform this test. With this data, we can differentiate total credit into free-purpose loans and purpose loans (loans for acquisition of assets or for the financing of

\footnotetext{
${ }^{37}$ Under this new financial system, the fiduciary lien was considered to be the main collateral, in which individuals who were trying to finance the acquisition of a house would pledge this same house as collateral.

${ }^{38}$ Despite it being created in 1997, some specialists have argued that this contract did not improve creditor rights significantly in the short run due to several judicial insecurities at that time. One of the issues was the introduction of the patrimônio de afetação, which was only solved in 2004, as discussed above. Another one was the judicial debate regarding whether creditors could not liquidate a "family asset", such as the house they live in. This pro-debtor stance was meant to protect the weaker link of a borrowing contract and avoid families losing their own house and becoming a burden to social security. This issue was greatly solved with the new Civil Code of 2002 that introduced in ts article 422 the principle of "good faith".

${ }^{39}$ Other uses for the fiduciary lien, such as home-backed loans, were not explicitly allowed at the time. Given that this law was related to real estate acquisition financing, the judicial understanding at the time was that fiduciary lien was only to be used for acquisition of real estate assets.
} 
production costs). We then employ a similar identification strategy as in section 4.1 but now expecting credit in municipalities with low homeownership - i.e., a high proportion of households who are renting their homes - to react post-November 1997. We take data on the fraction of households who are rented per municipality from the Brazilian Census of 1991, thus before the 1997 law.

In Table A1, we show that low homeownership municipalities experience a drop in bank credit (column I). This result suggests that the fiduciary lien also had an effect on lending in 1997 despite all the initial challenges with this law. Also, this increase in lending appears to be specific to purpose loans (column III), while being insignificant for free-purpose loans (column II). Finally, we also find that owned households increase more in areas that had low homeownership before in 1991, which means that the fiduciary lien in 1997 indeed helped to alleviate the housing deficit in Brazil in line with the government's goal. Overall, these results are consistent with the 1997 law affecting mainly real estate lending and not other types of bank credit. There was indeed the need for another law in 2004 to consolidate the fiduciary lien and expand its scope to become collateral of any debt obligation.

\section{A.2 Direct Effects: Other Specifications}

In this section, we provide other robustness tests for our direct effects results.

In Table A2, we add specifications where we regress the growth in the log of home-backed loans (columns I and II) and total credit (columns III and IV) on homeownership, but controlling for the log of income per capita and its square as controls. In our benchmark results in Table 2, we control for terciles of income per capita. Controlling for the linear and quadratic function of log income per capita would be a stricter specification. Table A2 shows that our results are quantitatively and qualitatively the same. Home-backed loans and total credit still increase in areas with higher homeownership.

Table A2: Direct Effects: Additional Controls of Income Per Capita

\begin{tabular}{|c|c|c|c|c|}
\hline & \multicolumn{2}{|c|}{$\Delta \ln (\text { home-backed loans })_{m b}$} & \multicolumn{2}{|c|}{$\Delta \ln (\text { total credit })_{m b}$} \\
\hline & I & II & III & IV \\
\hline Homeownership $_{m}$ & $\begin{array}{c}0.129 * * * \\
(0.026)\end{array}$ & $\begin{array}{c}0.150 * * * \\
(0.026)\end{array}$ & $\begin{array}{l}0.032 * * \\
(0.0141)\end{array}$ & $\begin{array}{l}0.035 * * \\
(0.0143)\end{array}$ \\
\hline Ln(Inc Per Capita $)_{m}$ & $\begin{array}{c}-0.046 \\
(0.0311)\end{array}$ & $\begin{array}{c}2.700 * * * \\
(0.4736)\end{array}$ & $\begin{array}{c}-0.095 * * * \\
(0.0133)\end{array}$ & $\begin{array}{c}0.193 \\
(0.2449)\end{array}$ \\
\hline Ln(Inc Per Capita $)_{m}^{2}$ & & $\begin{array}{c}-0.090 * * * \\
(0.0162)\end{array}$ & & $\begin{array}{c}-0.010 \\
(0.0084)\end{array}$ \\
\hline Obs & 18,561 & 18,561 & 72,007 & 72,007 \\
\hline Region FE & $\mathrm{Y}$ & $\mathrm{Y}$ & $\mathrm{Y}$ & $\mathrm{Y}$ \\
\hline Bank FE & $\mathrm{Y}$ & $\mathrm{Y}$ & $\mathrm{Y}$ & $\mathrm{Y}$ \\
\hline
\end{tabular}

This Table presents additional results of the direct effects of the housing collateral law of 2004. Inc per Capita is the ratio between municipality $m$ 's total income and total number of households. See Table 2 for the description of the other variables. Robust standard errors are presented in parenthesis. *,**, and *** denote significance of $10 \%, 5 \%$, and $1 \%$, respectively. 
In Figure A1, we present results of our benchmark but sequentially removing municipalities of each Brazilian region, i.e., North, Northeast, Southeast, South, and Midwest. The objective of this test is to show that our results are not dependent on a small cluster of municipalities concentrated in a specific region. By sequentially removing municipalities from each Brazilian region, we see that our results are still positive and significant. Removing municipalities from the North, Northeast, South, and Midwest from the analysis barely changes the estimated coefficients.

Removing municipalities from the Southeast, however, decreases the coefficient to 9\%, but still highly significant. This change suggests that effects are stronger in the Southeast, where cities like São Paulo and Rio de Janeiro are located. Nevertheless, our results still hold even when we do not consider municipalities from this region.

Figure A1: Direct Effects: Sequentially Removing Municipalities of each Brazilian Region

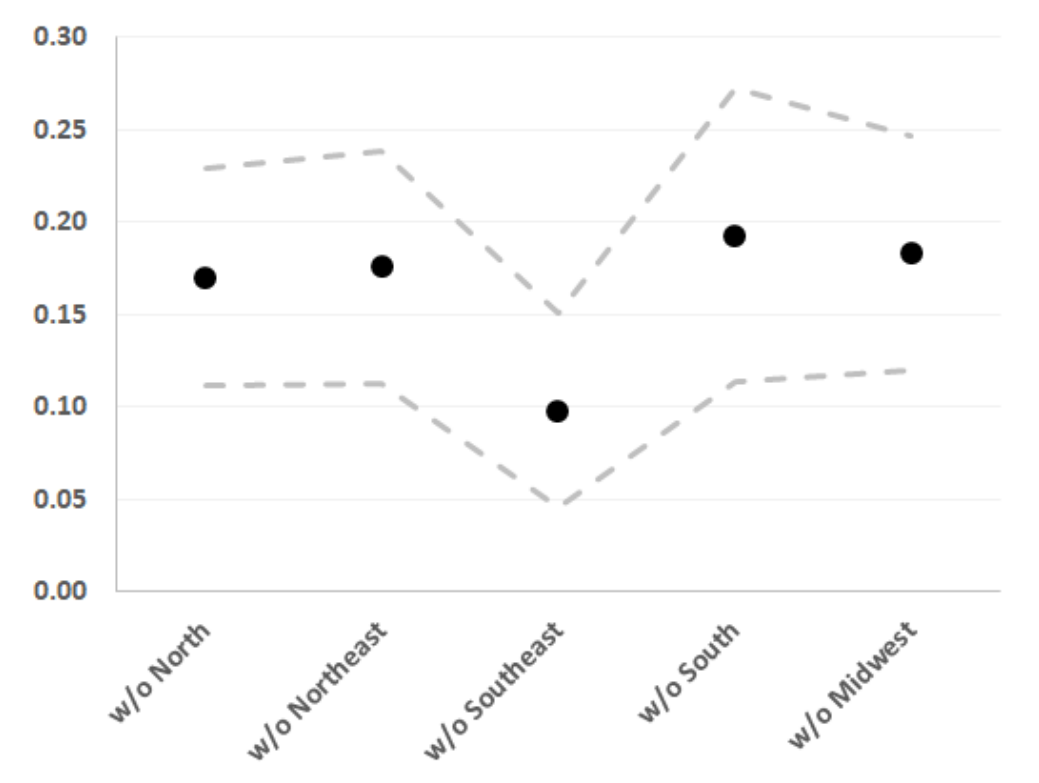

In our main specifications, we have showed that total credit (to both firms and individuals) increase in areas with higher homeownership. In Table A3 below, we show that this is also true for total credit to individuals only.

Table A3: Direct Effects: Total Credit to Individuals

\begin{tabular}{lccc}
\hline \hline & \multicolumn{3}{c}{$\Delta \ln$ (total credit to individuals) $)_{m b}$} \\
\cline { 2 - 4 } & I & II & III \\
\hline Homeownership $m$ & $0.111^{* * *}$ & $0.108^{* * *}$ & $0.082^{* * *}$ \\
& $(0.0168)$ & $(0.0100)$ & $(0.0100)$ \\
\hline Obs & 65,942 & 65,942 & 63,799 \\
Bank FE & $\mathrm{Y}$ & $\mathrm{Y}$ & \\
Region FE & & $\mathrm{Y}$ & \\
Bank * Inc per Capita * Region FE & & & $\mathrm{Y}$ \\
\hline \hline
\end{tabular}

This Table presents regressions of the growth in the log of total credit to individuals on homeownership results as additional evidence of the direct effects of the housing collateral law of 2004. See Table 2 for description of the other variables. Robust standard errors are presented in parenthesis. *, **, and *** denote significance of $10 \%, 5 \%$, and $1 \%$, respectively. 


\section{A.3 Bolsa-Família Program and Homeownership}

Around the same time as the passage of the housing collateral reform, the government started implementing a large cash transfer policy to low-income households called "Bolsa-Familia". This program might have benefited areas with higher homeownership and could have driven our results in terms of higher credit and higher real economic activity in those areas. This concern is particularly valid since areas with higher homeownership are those with lower average income.

To address this concern, we take data on the disbursements as well as the number of beneficiaries associated with the program from the Citizenship Ministry. Table A4 presents the difference-in-difference results when we compare the total disbursement value and the average number of beneficiaries in the first seven months of 2004, i.e., before the housing collateral law, and in the seven months of 2007 for municipalities with different homeownership rates. In none of the specifications we find that municipalities with higher homeownership experience a higher growth in disbursements of the Bolsa-Familia Program. As expected, columns III and VI show that municipalities with lower average income are the ones that experience a higher growth in Bolsa-Familia in 2007 versus 2004.

Table A4: Bolsa-Família Program and Homeownership

\begin{tabular}{|c|c|c|c|c|c|c|}
\hline & \multicolumn{3}{|c|}{$\Delta \ln (\text { value })_{m}$} & \multicolumn{3}{|c|}{$\Delta \ln (\# \text { beneficiaries })_{m}$} \\
\hline & I & II & III & IV & $\mathrm{V}$ & VI \\
\hline \multirow[t]{2}{*}{ Homeownership $_{m}$} & 0.007 & -0.014 & -0.008 & 0.008 & -0.013 & -0.008 \\
\hline & $(0.014)$ & $(0.015)$ & $(0.015)$ & $(0.014)$ & $(0.015)$ & $(0.015)$ \\
\hline \multirow[t]{2}{*}{$\operatorname{Ln}(\text { Inc per Capita })_{m}$} & & & $-0.110 * * *$ & & & $-0.121 * * *$ \\
\hline & & & $(0.036)$ & & & $(0.037)$ \\
\hline Obs & 5,412 & 5,412 & 5,412 & 5,412 & 5,412 & 5,412 \\
\hline Region FE & Yes & & Yes & Yes & & Yes \\
\hline Region * Inc per Capita FE & & Yes & & & Yes & \\
\hline
\end{tabular}

This Table presents regressions of Bolsa-Família's disbursements on homeownership around the housing collateral law of 2004. We take information on Bolsa-Família's disbursements from the Citizenship Ministry. In columns I to III, the dependent variable is the growth in the log of the total value of the disbursements from the first seven months of 2004 to the first seven months of 2007 in municipality $m$. In columns IV to VI, the dependent variable is the growth in the log of the average number of beneficiaries of the program from the first seven months of 2004 to the first seven months of 2007 in municipality $m$. Robust standard errors are presented in parenthesis. *,**, and *** denote significance of $10 \%, 5 \%$, and $1 \%$, respectively.

\section{A.4 Evolution of Home-Backed Loans}

Figure A2 shows the evolution of home-backed loans across loan-modalities and time.

There are three different points to highlight from this graph. First, the most common use of homebacked loans is to finance the acquisition of non-real estate assets (i.e., financing with a specific purpose). This is then followed by credit lines and other forms of financing. 
Figure A2: Evolution of Home-Backed Loans

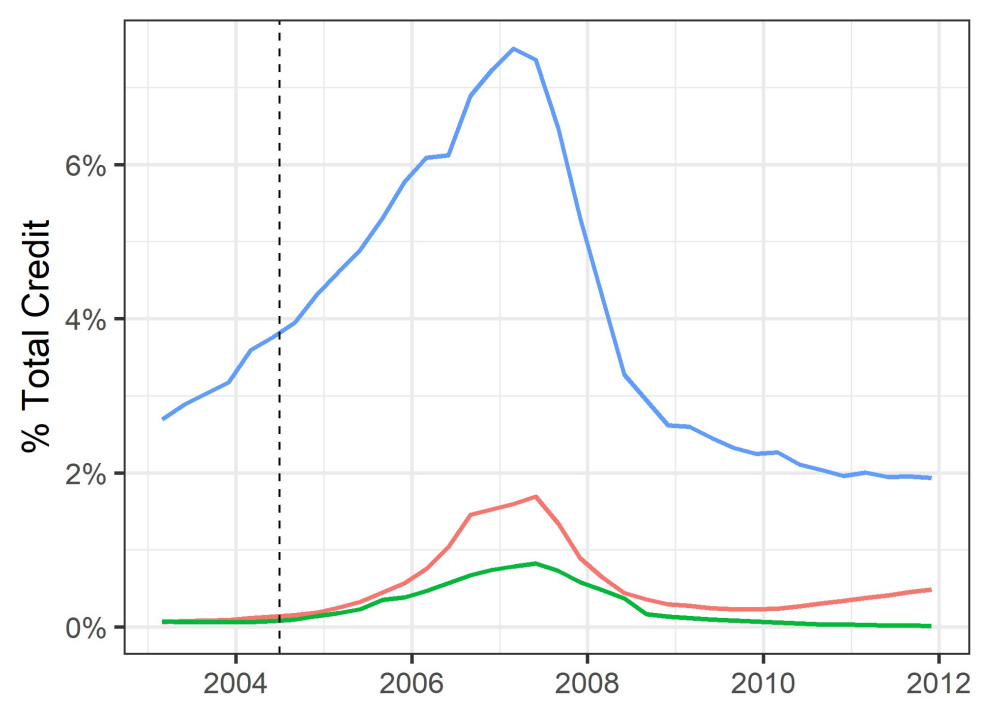

Loan Purpose

- Credit line (home equity)

- Leasing and others

- Specific purpose (financing)

Second, home-backed loans increase after the housing collateral reform across all of these loan modalities. For instance, home-backed loans used for specific purposes increases from around $3 \%$ of total credit in 2003 to almost $8 \%$ in 2007. Home-equity loans-i.e., loans backed by the value of the house used for any purpose-were almost nonexistent in 2003 and increased to almost $2 \%$ in 2007.

Finally, after the financial crisis of 2007-08, home-backed loans decrease significantly in importance. Even though an analysis of why this happened is outside the scope of this paper, we hypothesize that this decrease was due to some underlying characteristics of the fiduciary lien contract. Most importantly, this collateral contract is a non-recourse loan. In the case of default and when the outstanding debt surpasses the value of the house, the bank cannot go after the borrower to recover the residual value of the debt after liquidation. In other words, the acts of repossession and liquidation of the collateral automatically mean that any remaining debt is forgiven. Thus, the fiduciary lien benefits creditors mainly in expansions of the business cycle and housing prices, but not in moments of contraction. 